\title{
Decifrando mapas:sobre o conceito de "território" e suas vinculações com a cartografia'
}

\author{
Beatriz Piccolotto Siqueira Bueno \\ Depto. de Históiria da Faculdade \\ de Arquitetura e Urbanismo da USP
}

RESUMO: $\bigcirc$ ensaio versa sobre a documentação cartográfica legada pelos engenheiros militares, em Portugal, no século XVIII. Analisa a dimensão técnica da produção de mapas, focalizando os instrumentos e os métodos empregados nos levantamentos de campo e no desenho de gabinete. Do ponto de vista da cultura material, os mapas são interpretados como artefatos culturais e, portanto, históricos; dessa forma, as particularidades da linguagem cartográfica revelam as concepções de mundo, o estado do conhecimento científico, as convenções e os códigos de representação próprios de cada período. Propõe uma metodologia de análise morfológica da linguagem cartográfica, desconstruindo os diversos estratos da tessitura desse tipo de representação visual. Para tanto, mobiliza um vasto campo de documentos correlatos, heterogêneos, tais como tratados de geometria prática, desenho e arquitetura, contemporâneos ao objeto de estudo.

PALAVRAS-CHAVE: Cartografia histórica. Engenheiros militares. Brasil. Século XVIII. Linguagem cartográfica.

ABSTRACT: This essay studies the cartographic documentation left by military engineers in Portugal, during the 18th Century. The technical dimension of map making is analysed, focusing on the instruments and the methods employed both in field surveys and in subsequent graphic representations. From the point of view of Material Culture, maps are understood as cultural artefacts, therefore historical artefacts; in this sense, the particularities of cartographic language reveal the world conceptions particular to each period. This article proposes a methodology of morphological analysis of the cartographic language, deconstructing the several strata in the organisation of this kind of visual representation. In order to do so, a vast array of heterogeneous correlate documents is mobilised, such as practical geometry, drawing and architecture treatises, contemporary to the period studied.

KEYWORDS: Historical Cartography. Military Engineers. Brazil. 18th Century. Cartographic Language.

\author{
1. Este ensaio é parte da \\ nossa tese de doutorado, \\ intitulada Desenho e de- \\ sígnio: o Brasil dos enge- \\ nheiros militares (1500- \\ 1822), defendida na FAU/ \\ USP, em 2001, e realizada \\ sob a orientação do Prof. \\ Dr. Nestor Goulart Reis \\ Filho. As considerações \\ aqui presentes são uma \\ síntese dos conteúdos \\ desenvolvidos nos capí- \\ tulos II, III e V, com nova \\ arquitetura.
}


Optamos por interpretar os mapas elaborados pelos engenheiros militares portugueses setecentistas do ponto de vista da cultura material, circunscrevendo nossa atenção no seu processo de produção - do levantamento de campo ao desenho de gabinete - e nos seus aspectos morfológicos, como amálgama de saberes diversos, sobretudo provenientes das Matemáticas aplicadas - Geometria prática euclidiana, Geografia e Astronomia - e das Belas-artes - desenho e pintura.

Para tanto, abordamos indiretamente questões de História da técnica, História da ciência e História da cultura, mobilizando uma série conexa de documentos contemporâneos ao objeto de estudo, heterogêneos, tais como tratados de Geometria prática, Desenho e Arquitetura italianos, franceses e portugueses.

Convém mencionar que, ao contrário dos cosmógrafos encarregados de realizar as cartas náuticas e auxiliar no processo de expansão ultramarina portuguesa, a partir do fim do século XVI, coube aos engenheiros militares realizar o mapeamento (geográfico, corográfico e topográfico) e efetivar a conquista das terras descobertas, auxiliando a Coroa nos seus desígnios de conhecimento e definição de "territórios".

Longe de serem uma reprodução fidedigna do real, mapas são representações. A transposição dos levantamentos de campo para o papel implica a representação gráfica da natureza por meio de uma série de convenções e códigos de representação. Em vez de questionar a precisão e o rigor dos nossos primeiros mapas, achamos interessante observar as condições técnicas da sua produção. Apesar de dizerem mais do que mil palavras, mapas merecem cuidados na interpretação da sua linguagem.

Para uma análise dos diferentes níveis de representação, partimos da metodologia de desconstrução ${ }^{2}$ proposta por Christian Jacob. Esse autor parte do pressuposto que as cartas são objetos culturais, nos quais coexistem e se justapõem diferentes estratos e códigos figurativos. Essa intertextualidade pressupõe um estudo análogo à análise morfossintática de um texto. As particularidades gráficas revelam determinadas escolhas culturais, concepções de mundo, estado do conhecimento científico e convenções cartográficas - medidas, códigos de figuração, paleta cromática, grafismos, ornamentos - próprios de cada período.

A indiscutível beleza dos mapas setecentistas portugueses nos remete à indagação: quais os instrumentos, técnicas e convenções empregados na sua feitura? Como os engenheiros militares, em Portugal e no Brasil, realizavam os levantamentos de campo, preparavam seu gabinete, sua mesa de trabalho, suas folhas de papel, seu estojo de desenho? Como riscavam as primeiras linhas a lápis, apagavam-nas com miolo de pão, preparavam as penas, empunhavamnas corretamente, riscavam a nanquim, preparavam as tintas, davam as aguadas, colavam as diversas folhas, ornamentavam o conjunto? 
Geografia é uma palavra de origem grega que significa desenhar ou escrever a terra. A História da Geografia é em grande parte aquela da lenta conquista do globo terrestre: "processo nel quale si sovrappongono strati di conoscenze, di localizzazioni, di geometrizzazione, di misurazioni parziali, di toponimi, di abbozzi cartografici" (JACOB, 1996, p. 901-903).

Segundo Christian Jacob, "a carta é uma imagem plana da terra ou de uma de suas regiões" (UACOB, 1992, p. 29)-mediação, interface, dispositivo abstrato de linhas, códigos, cores e inscrições, miniaturização esquemática e simbólica da natureza, em suma, representação, fruto de um paciente trabalho de construção técnica, de convenções gráficas e artifícios visuais. A carta não é uma categoria anistórica ou transcultural, apresentando lógicas específicas em diferentes contextos. Instrumentos de comunicação (JACOB, 1992, p. 137-1 38), por meio de jogos analógicos, os mapas geográficos, corográficos e topográficos representam, em escalas diversas, o espaço terrestre. Nos mapas, sobre uma trama ortogonal, encontra-se representada uma "visão de mundo" em duas dimensões. As cartas nos trazem uma realidade nova, abstrata e simbólica, segundo convenções sociais validadas pelo uso, que fazem com que numa certa época e sociedade se reconheça o mundo sobre o qual se vive numa determinada configuração gráfica.

Carta vem do latim tardio carta, que deriva do grego khártés, em italiano é carta e em inglês chart. Designativo genérico, para o fim que nos interessa cabe precisá-lo em: carta geográfica ${ }^{3}$ (terrestre geral), carta corográfica ${ }^{4}$ (terrestre regional), carta topográfica (terrestre local), cartas náuticas ${ }^{5}$ e cartas cosmográficas ${ }^{6}$ (planisférios, mapas-múndi):

Chamamos Cartas Topograficas as cartas particulares, que representão sobre hum plano huma pequena parte da terra, como por exemplo Lisboa, e seu termo, ou quando muito huma Provincia, como a Estremadura; e nestas Cartas particulares, alèm das Cidades, Villas, Aldeas, Castellos, \&c. se representão os montes, os valles, os outeiros, os Rios, Ribeiras, e lagos, os prados, os matos, as charnecas, e terras lavradas, planas, ou montanhosas; chamamos Cartas Chorograficas aquellas, que representão sobre hum plano huma parte consideravel da terra, como hum reyno, por exemplo o de Portugal, e cartas grandes as que representão huã das partes da terra, como Europa, ou Africa, \&c.; Carta Geral he aquella, que representa toda a superficie da terra em hum plano, por cuja razão se chama Planispherio, ou Mappa Mundi. (FORTES, 1722, p. 191-193)

Em inglês, carta também se diz map e encontramos esse radical ainda no espanhol e no português. A origem de map é o latim mappa. Em italiano encontramos três termos para designar as cartas geográficas: mappa, carta e piano (plano). Em meio aos já citados, outros termos surgiram - pictura, mappa mundi - e, na ldade Média e no Renascimento, consagraram-se duas expressões imago e descriptio. $\bigcirc$ termo geographos parece ter origem em Eratóstenes /séc. III a.C.I, significando aquele que descreve/desenha a terra, termo ambíguo que ou de alguã parte della em huma, ou em muitas grandes folhas de papel". Cf. BLUTEAU, 1712, p. 167.

4. "Carta, em que se vê só a descripção de algum paìs, ou lugar.'Tabula Chorographica', ou 'Tabula Topographica'”. Cf. BLUTEAU, 1712, p. 167.

5. "Carta de Marear. He a que representa em plano todo o globo da terra, ou parte delle, descrita cõ todos os rumos da agulha de marear. Nela se conhece o tempo dos mares, \& em que se vem os penedos, cachopos, bãcos de area, \& outras perigosas paragens do mar. Por ella sabe o piloto, qual o vento ha mister, \& juntamente a altura, que tem o lugar, para onde ha de encaminhar sua nao. "Marina Tabula, \&, ou Naútica Tabula, ae. Fem." Cf. BLUTEAU, 1712, p. 167.

6. "Carta Cosmographica - carta universal, em que o mundo todo está representado". Cf. BLUTEAU, 1712, p. 167. 
7. "É difficile negare che sussistano evidenti analogie, almeno a livello di strumentazione mentale, tra i metodi proposti da Tolomeo per la proiezione della sfera sul piano a fini della rappresentazione cartografica e la definizione di rigorose regole geometriche per la costruzione della griglia prospettica di un disegno o di un dipinto. È forse ecces sivo, forzando queste analogie,sostenere - come ha fatto Samuel Edgerton $\mathrm{Jr}$. - che i metodi di proiezione illustrati nella 'Geographia' (soprattutto il terzo, che peraltro non vi trovava concreta applicazione) abbiano direttamente ispirato lo sviluppo quattrcentesco della prospettiva lineare. Resta tuttavia il fatto che i problemi era no della stessa natura: ri condurre le tre dimensioni in una raffigurazione bidimensionale che ne conservasse le proporzioni Non sorprende quindi di trovare spesso nel Quattrocento le stesse persone impegnate nelle indagini geografiche così come nell'elaborazione teorica della prospettiva. Bas ti pensare all'Alberti, attratto costantemente dagli studi geografici e dai metodi di proiezione cartografica, come doveva mostrare la sua innovativa e 'tolemaica' nello spirito 'Descriptio Urbis Romae' (Descrizione della città di Roma), [...], ma anche teorico eccelso della costruzione prospettica nel 'De pictura'. Lo stesso vale per Paolo dal Pozzo Toscanelli, probabile ispiratore dell'esperimento prospettico di Brunelles chi e autore di un perduto trattato sulla prospettiva, ma anche protagonista degli studi geografici e cartografici”. Cf. GALLUZ ZI 2000, p. 31. diz respeito tanto a uma versão descritiva literária quanto a uma versão desenhada em carta, já que o verbo graphein significava simultaneamente escrever, desenhar e pintar. Por sua vez a distinção entre cosmógrafos e geógrafos tem origem em Ptolomeu (séc. II), datando de 1557 a aparição do termo géographe na língua francesa, como aquele que desenha cartas; no momento em que se observava uma especialização dos saberes, coube ao cosmógrafo realizar as cartas náuticas e aos geógrafos as cartas terrestres.

Termos genéricos e atuais como cartógrafo e cartografia são neologismos que encobrem nuanças semânticas fundamentais para a compreensão histórica do objeto em questão (JACOB, 1992, p. 37-40). Inexistente até o século XIX, a palavra cartografia foi criada pelo historiador português Manoel Francisco de Barros e Sousa (179 1-1865), II visconde de Santarém, conforme carta datada de Paris, a 8 de dezembro de 1839, e endereçada ao historiador brasileiro Francisco Adolfo Varnhagen, na qual se diz: "invento esta palavra, já que aí se tem inventado tantas" (ÁVILA, 1993, p. 110).

As escalas geográfica e corográfica: o problema da longitude

As origens da história da cartografia estão na Grécia helenística. Os conhecimentos cartográficos do mundo antigo foram sintetizados e alcançaram seu ponto culminante na obra de Ptolomeu. Nascido em Alexandria, no século II (ca. 100-ca. 178), dedicou dois volumes da sua Cosmografia ao estudo da construção de globos, projeções e mapas. Considera-se ser esse o primeiro atlas geral elaborado com paralelos e meridianos. Os manuscritos de Ptolomeu foram profundamente estudados no Quattrocento, e os humanistas italianos os traduziram para o latim. A editio princeps foi publicada, sem cartas, em Vicenza, em 1475. Na sua dedicatória ao papa Alessandro V, lacopo Angeli, "sottolineava opportunamente che la maggiore novità della 'Geografia' consisteva non tanto nella pur dettagliata descrizione dell'intero mondo abitado, quanto nel modo adottato per raffigurarlo" (GALLUZZI, 2000, p. 28). A edição de 1507 mudou o título de Cosmografia para Geografia, atualizando o tratado com lugares novos, então descobertos. Em Portugal, a obra de Ptolomeu foi amplamente estudada e divulgada pelo cosmógrafo-mor Pedro Nunes.

A novidade da obra de Ptolomeu residia no fato de ensinar o método para se projetar a esfera terrestre sobre um plano, de forma a manter a "proportio cuiusque partis ad universale" -, ou seja, "ricondurre le tre dimensioni in una raffigurazione bidimensionale che ne conservasse le proporzioni"7. Para tanto, o cosmógrafo grego introduziu uma espécie de trama ortogonal, dotada de linhas paralelas (as latitudes) e meridianas (as longitudes), que permitiram representar graficamente a posição de cada lugar sobre o globo terrestre: "Egli mostrava, infine, come la 'pittura del mondo' potesse essere divisa in numerose tavole parziali nelle quali veniva sempre mantenuta la proporzione rispetto al tutto" (GALLUZZI, 2000, p. 28). 
Enquanto o grau zero ou primeiro paralelo da latitude foi fixado pelas leis da natureza (linha do Equador), o grau zero do meridiano da longitude variou conforme os interesses em questão. $\bigcirc$ posicionamento do primeiro meridiano foi sempre uma decisão política. Ptolomeu convencionou a linha do meridiano sobre a llha do Ferro (llhas Canárias), ponto mais extremo, a oeste, do mundo conhecido de então. Depois os cartógrafos a mudaram arbitrariamente para os Açores, a llha de Cabo Verde, Roma, Copenhague, Jerusalém, São Petersburgo, Pisa, Paris, Filadélfia, entre outros lugares, antes de fixá-la em Londres (Observatório de Greenwich) ${ }^{8}$ (Figura 1).

○ cálculo da latitude era feito pela observação da altura do Sol ou estrelas - a estrela Polar no hemisfério Norte e o Cruzeiro do Sul no hemisfério Sul -, com o auxílio de um astrolábio, quadrante ou balestilha. $\bigcirc$ cálculo da longitude não era tão simples assim e demandou pesquisas e concursos, envolvendo premiações em dinheiro, patrocinados por reis e príncipes das mais importantes potências marítimas européias entre os séculos XVI e XVIII, como Espanha, províncias holandesas, Cortes italianas, Inglaterra e França. A Terra é uma circunferência de $360^{\circ}$ que leva 24 horas para dar uma volta em torno de si, cada hora correspondendo a $15^{\circ}$. A medida da longitude dependia, portanto, da medida do tempo (saber a hora exata no ponto de partida e a correspondente hora exata no ponto de chegada, convertendo a diferença de horas entre ambos em extensão geográfica percorrida). Seria tudo muito fácil nos tempos dos nossos

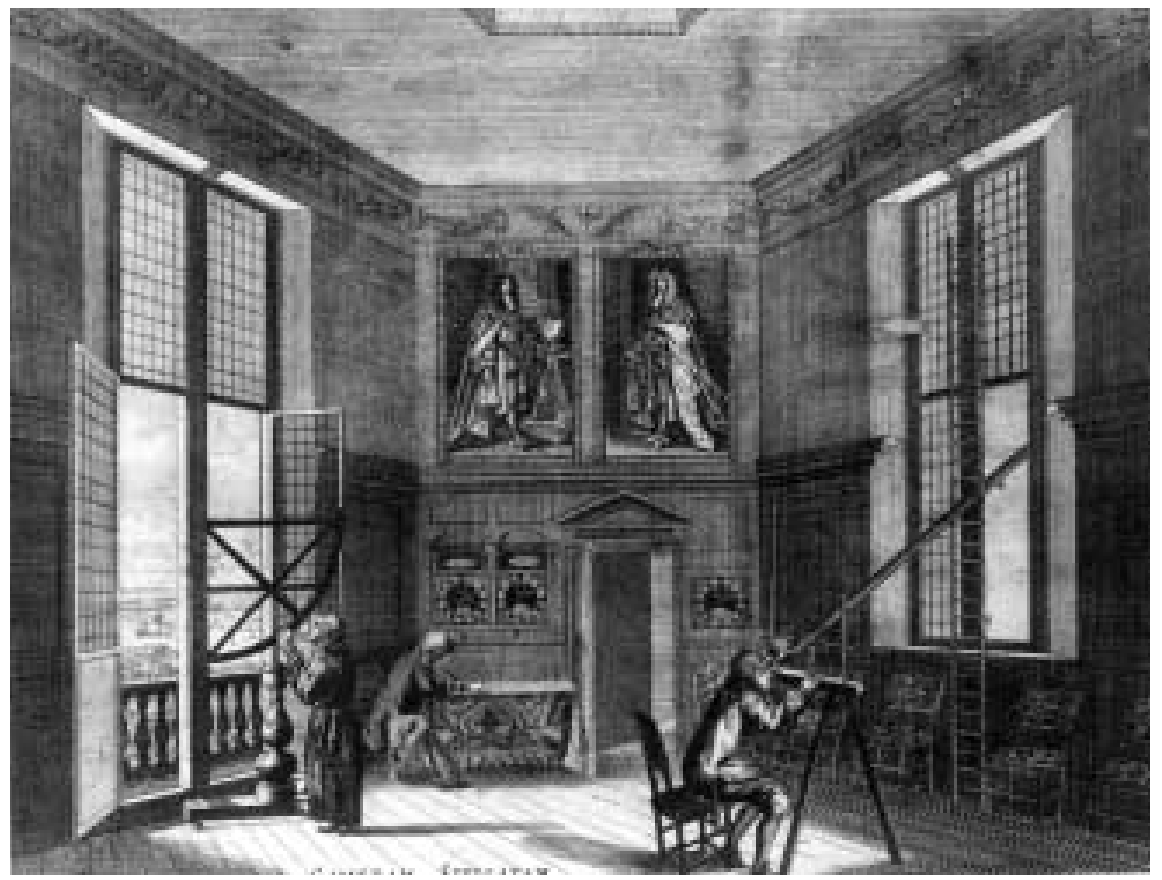

Fig. 1 - "Prospectus Intra Camera Stellata". Autor: PLACE, Francis. London \& Westminster, c. 1676, vol. 1. Gravura copiada por Samuel Pepys, em 1700. Original: Pepys Library, Magdalene College, Cambridge. Fonte: SOBEL, D.; ANDREWES, W. J.H. The Illustrated Longitude. New York: Walker and Company, 1998, p. 41.
8. SOBEL; ANDREWES, 1998, p. 4-5. 
9. O inglês John Harrison entre 1730 e 1770 (1737, $1741,1759,1760,1770)$ inventou cinco revolucionários relógios portáteis e precisos, pondo fim ao maior e quase insolú vel problema científico do seu tempo: a longitude. Cf. SOBEL, 1995.

10. SOBEL. op. cit., 1998 p. 293 modernos relógios de pulso ou cronômetros altamente precisos. No entanto, essa conquista só veio a ocorrer no fim do século XVIII. Até a famosa invenção de John Harrison (1770), os relógios eram passíveis de oscilação durante as viagens, comprometendo o cálculo da longitude. Qualquer variação de temperatura, pressão, movimentação dos navios ou do corpo nas longas caminhadas provocava-thes alterações. Entre 1730 e 1770, o inglês John Harrison inventou quatro revolucionários relógios portáteis e, em 1770, o relógio de bolso capaz de manter a hora, do ponto de origem em relação ao mais remoto e recôndito ponto de chegada do planeta (Figura 2).

Antes porém, os cálculos eram feitos pela observação dos eclipses das Luas de Júpiter, com o auxílio do telescópio, inventado por Galileu em $1610^{10}$ (Figura 3). O método de Galileu consistia na observação do eclipse de um dos

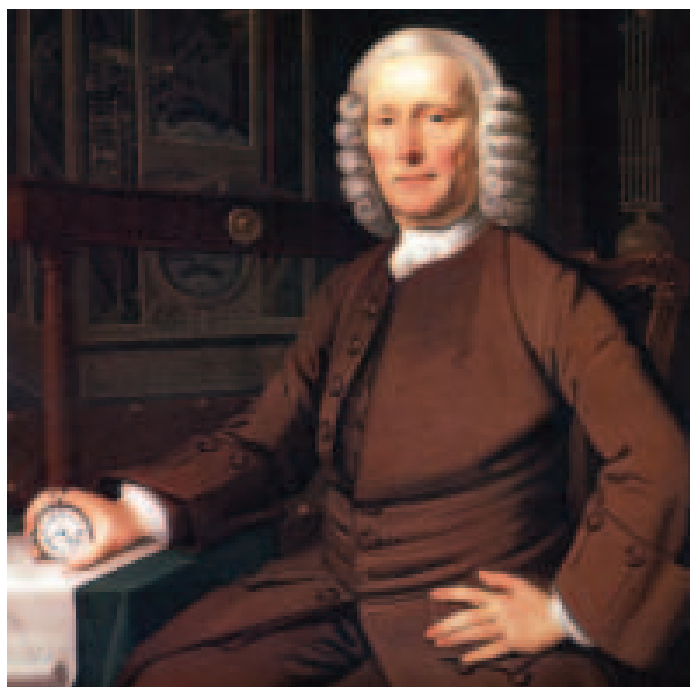

Fig. 2 - Retrato de John Harrison (16931776). Autor: Thomas King, c. 1766. Original: Science Museum, Science and Society Picture Library, London. Fonte: SOBEL, D.; ANDREWES, W. J.H. The Illustrated Longitude. New York: Walker and Company, 1998, p. 150.

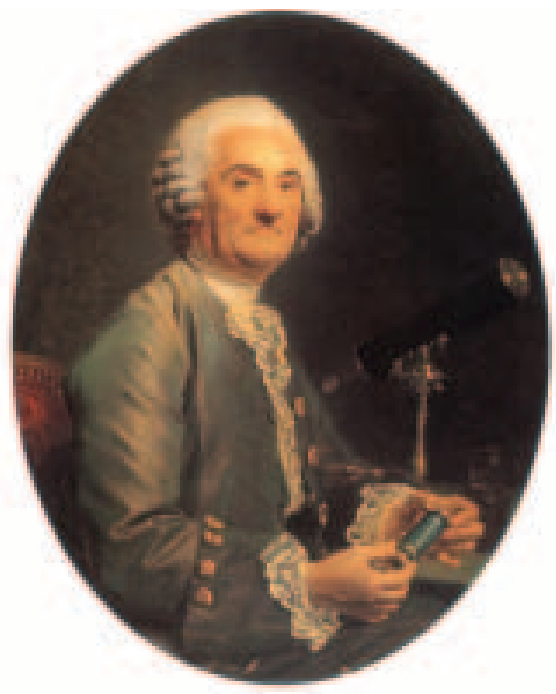

Fig. 3 - $\bigcirc$ Astrônomo. Autor: Nicolas Bernard Lépicié. Óleo sobre tela, c. 1777. Museu Calouste Gulbenkian, Lisboa, inv. 2385. Fonte: FERRAND DE ALMEIDA, A. Os jesuítas matemáticos e os mapas da América portuguesa (1720-1748). Oceanos, Lisboa, n. 40, p. 81,1999 
satélites do planeta Júpiter, para se determinar a diferença de longitude entre dois lugares. Tal como demonstra o desenho esquemático (Figura 4), num mesmo momento, era possível ver o satélite $(K)$ atrás de Júpiter $(U)$ em diferentes pontos $(R)$ e (Q) da Terra. Se o observador posicionado em $Q$ tivesse em mãos tabelas para comparar a hora do eclipse no ponto $R$, em relação à sua hora local, ele poderia encontrar a diferença de longitude entre os pontos $R$ - por exemplo, 3 horas da manhã - e $Q$ - meia-noite. Essas três horas de diferença significariam que $Q$ estava $45^{\circ}$ a oeste ${ }^{11}$ do ponto R. $\bigcirc$ eclipse da primeira lua de Júpiter (lo) funcionava como um relógio celeste: era um fenômeno freqüente, regular, portanto previsível. Galileu elaborou tabelas prevendo a periodicidade dos eclipses, depois aprimoradas e publicadas por Domenico Giovanni Cassini (1625-1712), da Academia Real de Ciências de Paris ${ }^{12}$. Em campo, em qualquer parte da Terra, no momento do dito eclipse, ajustava-se um relógio de pêndula com a hora de Paris presente na tabela publicada por Cassini, prevendo o fenômeno para aquele dia. Esperava-se a manhã seguinte e ao meio-dia (com um relógio de sol) se calculava a diferença de horas em relação a Paris (registrada na pêndula).

A escala topográfica: instrumentos e métodos empregados nos levantamentos de campo

Ao contrário das cartas geográficas e corográficas que representam grandes superfícies terrestres, demandando complexos cálculos de latitude e
11.1 hora $=15^{\circ}$, portanto 3 horas $\mathrm{x} 15^{\circ}=45^{\circ}$.

12. Em 1667 foi fundado o Observatório Astronômico de Paris, por Luís XIV, convertendo Paris no primeiro meridiano, a partir do qual os novos levantamentos geográficos deveriam partir. Cf SOBEL. op. cit., 1998, p 36. Em 1662, foi fundada a Royal Society of London e, em 1675, o Royal Observatory em Greenwich. Cf. SOBEL. op. cit., 1998, p. 39-40.

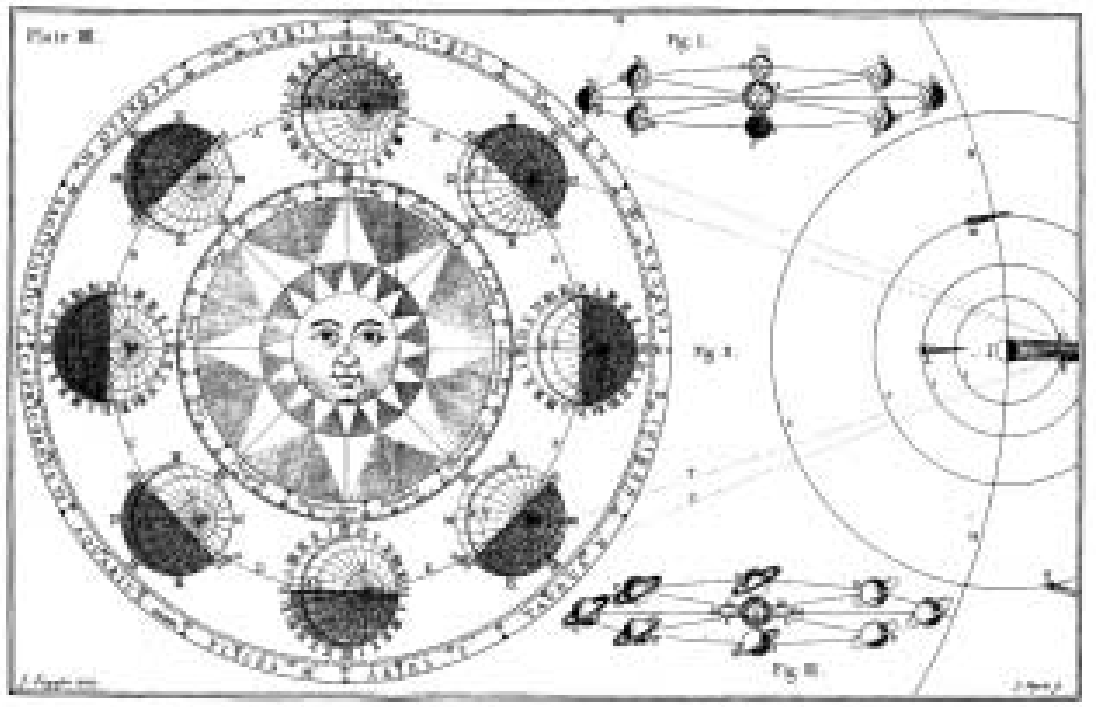

Fig. 4 - Diagrama ilustrando o eclipse de uma das luas de Jupiter. Autor: FERGUSON, James. Astronomy Explained. London, 1756, plate 4, p. 79. Houghton ( ${ }^{*}$ EC75.F38 13.7569). Fonte: SOBEL, D.; ANDREWES, W. J.H. The Illustrated Longitude. New York: Walker and Company, 1998, p. 31. 
13. A partir do Renascimento, os projetos arquitetônicos pressupunham um minucioso estudo do terreno no qual seria implantado o edifício. Nesse sentido, paralelamen te ao aperfeiçoamento das técnicas de representação gráfica, os arquitetos e engenheiros militares do Quattrocento de senvolveram modernas práticas de levantamento topográfico, herdeiras dos procedimentos da ciência náutica.

14.Cósimo Bartoli foi o editor e tradutor de uma série de trabalhos de Alberti, dentre eles o Ludi mate matici, cujo conteúdo in corporou no seu Modo de misurare... Entre as suas fontes, além de Alberti, são citados Orontius Finaeus, Albrecht Dürer, Archimedes, Euclides, Gemma Fr sius, Giovan Roia, Giovanni Stoflerino, Georg Peurbach, Peter Appianus, Ptolomeu e Vitrúvio. Nessa mesma época, encontravase às voltas com a tradução ilustrada do De re aedifi catoria, de Alberti, para a língua florentina (1550 1565). Como podemos verificar, os mesmos homens interessados com a questão da arquitetura, encontravam-se envolvidos com a temática da geometria prática (longimetria, altimetria, planimetria, estereometria e trigonometria). Utilizamos uma edição de 1589 , localizada na Biblioteca Nacional de Madri. longitude, as cartas topográficas representam áreas menores - um topos, ou seja, um lugar específico (uma vila e seu termo ou uma província). Embora menos complexas, as cartas topográficas também implicaram a elaboração de métodos específicos de levantamento de campo, desenvolvidos por arquitetos e engenheiros militares italianos, tais como Leon Battista Alberti' ${ }^{3}$, Mariano Taccola (Figura 5) e Francesco di Giorgio Martini, no século XV. Tais métodos cristalizaram-se no século XVI, sendo amplamente divulgados pelo tratado de Cósimo Bartoli'14 - Del

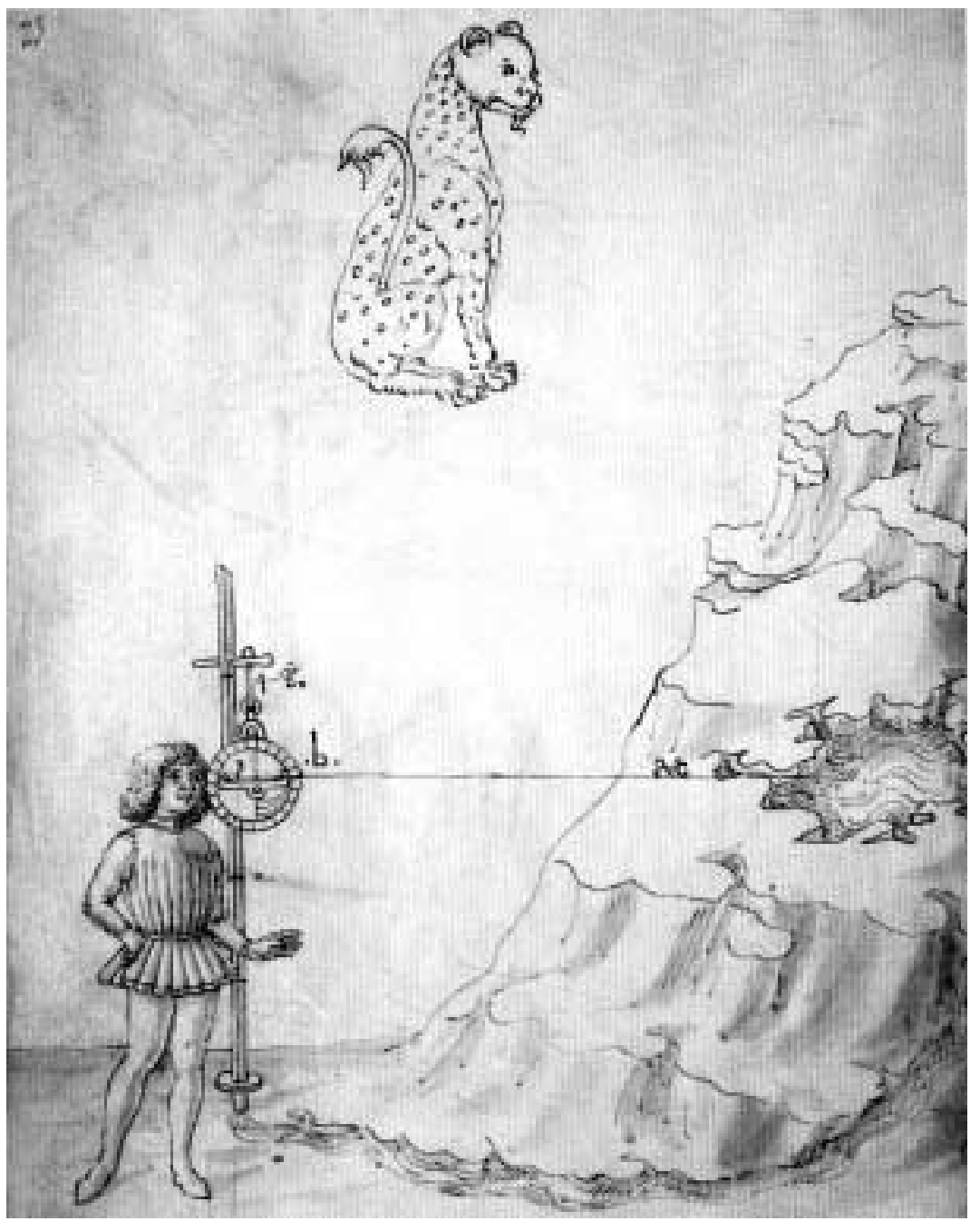

Fig. 5 - [Misurazione di dislivello con astrolabio]. Autor: Anônimo (atribuído a Mariano Taccola). Original: Biblioteca Nacionale Centrale, Firenze. Ms. Palatino 767, p. 23. Fonte: GALLUZZI, P. Gli ingegneri del Rinascimento da Brunelleschi a Leonardo da Vinci. Firenze: Istituto e Museo di Storia della Scienza/Giunti, 1996, p. 130. 
modo di misvrare le distantie, le superficie, i corpi, le piante, le prouincie, le prospettive, \& tutte le altre cose terrene, che possono occorrere a gli huomini. Secondo le vere regole d'Euclide, \& degli altri piu lodati scrittori - publicado em 1559. Além dos instrumentos empregados na ldade Média na medição de distâncias e alturas, Bartoli detalhou o método de levantamento topográfico envolvendo instrumentos originários da ciência náutica como o astrolábio e o quadrante. Em relação a Alberti (De re aedificatoria, 1452, livro X, cap. 7), a novidade apresentada em seu tratado residiu na possibilidade de empregar o astrolábio na medição não apenas da área de uma cidade, mas de uma província, tal como fizera Gemma Frisius, professor de matemática em Louvain, em 1533, utilizando-se do método de triangulação para uma extensão topográfica mais abrangente. A descrição de uma província e sua representação numa tavola plana era feita posicionando-se num lugar alto, com vista livre e desimpedida, e colocando a bussola piana con ago ${ }^{15}$ (circunferência graduada de $360^{\circ}$, com

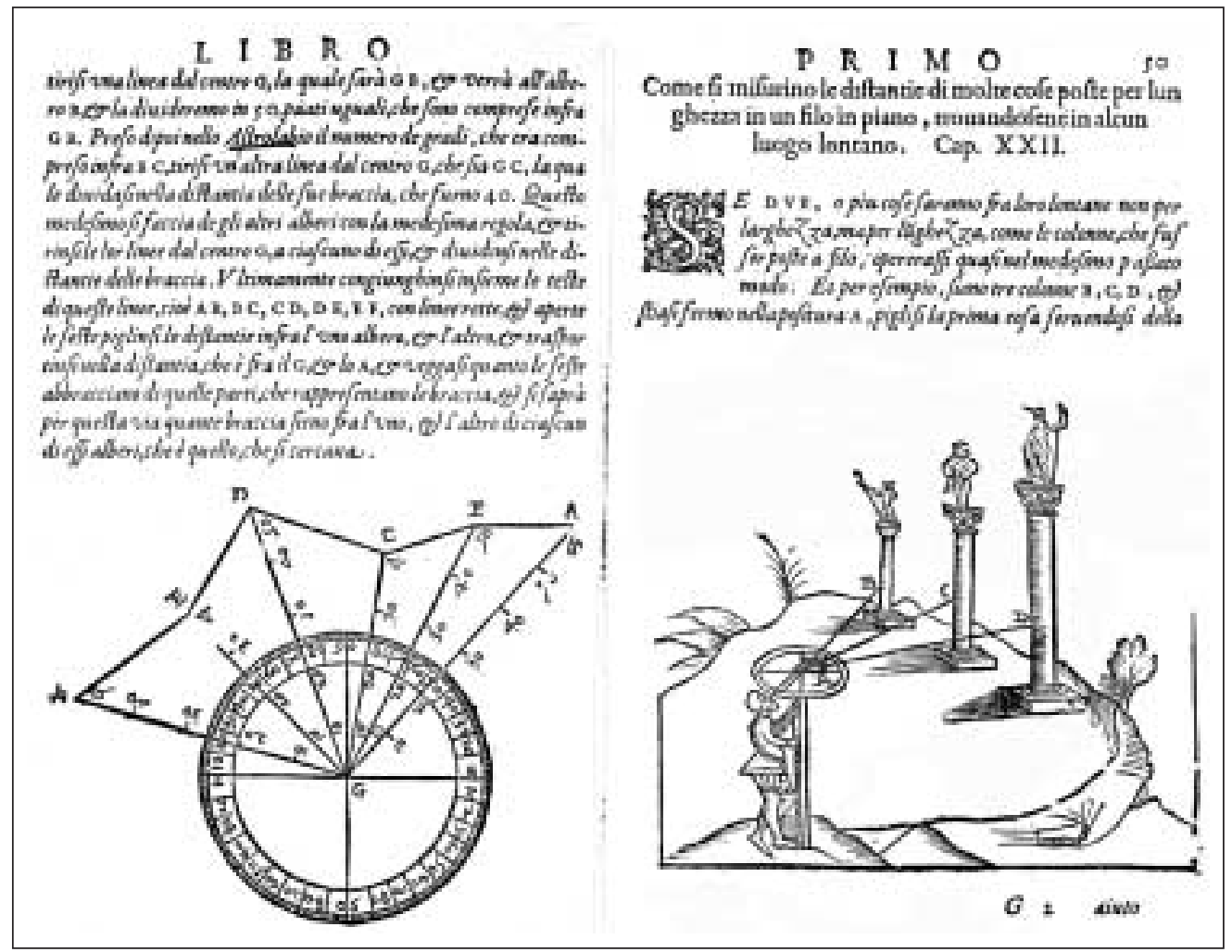

Fig. 6 - BARTOLI, Cosimo. Del modo di misurare le distantie, le superficie, i corpi, le piante, le provincie, le prospettive, \& tutte le altre cose terrestre, che possono occorrere a gli huomini, secondo le vere regole d'Euclide, \& degli altri piu lodati scrittori. Venetia: Per Francesco Franceschi Sanese, 1589, p.50. Biblioteca Nacional de Madrid. 
16. Norte magnético, onde sempre está a agulha quando descansa, descontando-se a impreci são em relação ao Norte verdadeiro.

17. GADOL, 1973, p $172 / 174$.

18. NUTI, 1993, p. 30 bússola e régua móvel com miras) na posição Tramontana ${ }^{16}$. Uma vez colocado o círculo de latão horizontalmente, mirava-se o lugar desejado e tomavam-se as linhas e ângulos de posição dos pontos selecionados em relação à Tramontana (Figura 6). Herdeiro do astrolábio náutico, tal instrumento foi chamado de horizonte por Alberti, polimetrum pelo cosmógrafo alemão Waldseemüller (ca. 1470-1521), circumferentor ou dutch circle por Gemma Frisius e torquetum por Tartaglia (15061557). Trata-se do mais remoto ancestral do nosso moderno teodolito, assim denominado, no século XVI, por Thomas Digges ${ }^{17}$.

Quase dois séculos mais tarde, o mesmo procedimento foi descrito no tratado de Manoel de Azevedo Fortes, O engenheiro portuguez (1728/1729), ou seja, ele ainda era válido em pleno século XVIII.

A uniformização da representação cartográfica

A transposição dos levantamentos de campo para o papel implica a representação gráfica da natureza por meio de uma série de símbolos convencionados. As cartas realizadas pelos cosmógrafos dos séculos XV e XVI nem sempre resultaram da observação direta. Quando se tratava de levantamentos de regiões longínquas, esses eram realizados por viajantes, pilotos náuticos ou locais, ocupando-se o cosmógrafo apenas do risco, aquarelamento e preparação dos atlas manuscritos em versões de luxo, muitas vezes acompanhados do texto explicativo redigido pelo próprio encarregado do levantamento. Quanto à linguagem dos mapas, convém ressaltar que um processo de uniformização se iniciou na ltália e na Holanda, a partir do século XVI. Até então as cartas, ainda pouco padronizadas, explicitavam o estilo pessoal de cada cosmógrafo, caracterizando-se pelo predomínio dos topônimos e figurações livres (Figura 7), que preenchiam as lacunas decorrentes do desconhecimento efetivo da região representada. Ao longo dos séculos XVII e XVIII, com a consolidação de convenções e códigos de representação cartográfica e a interiorização terrestre para além da faixa litorânea, tais figurações livres, quando existentes, foram relegadas ao âmbito da ornamentação dos cartuchos (molduras) de legendas e títulos.

A elaboração de convenções gráficas diferenciando espécies de árvores, por exemplo, foi introduzida pela edição ilustrada da Cosmografia de Ptolomeu, publicada em Roma em 1478, sendo que tal sistema de símbolos gráficos foi progressivamente aprimorado pelos tratados de agrimensura publicados pelos ingleses nos séculos subseqüentes. John Norden no fim do século seguinte introduziu outro complexo sistema de símbolos distinguindo categorias de cidades e edifícios significativos - vilas, capelas, castelos, monastérios, etc. ${ }^{18}$-, depois amplamente divulgado no tratado de Buchotte, Les règles du dessein et du lavis, de 1722. A trajetória dos símbolos cartográficos foi publicada por François Dainville em Le langage des géographes. Termes, signes, couleurs des cartes anciennes 1500-1800, em 1964 (Figuras 8 e 9). 


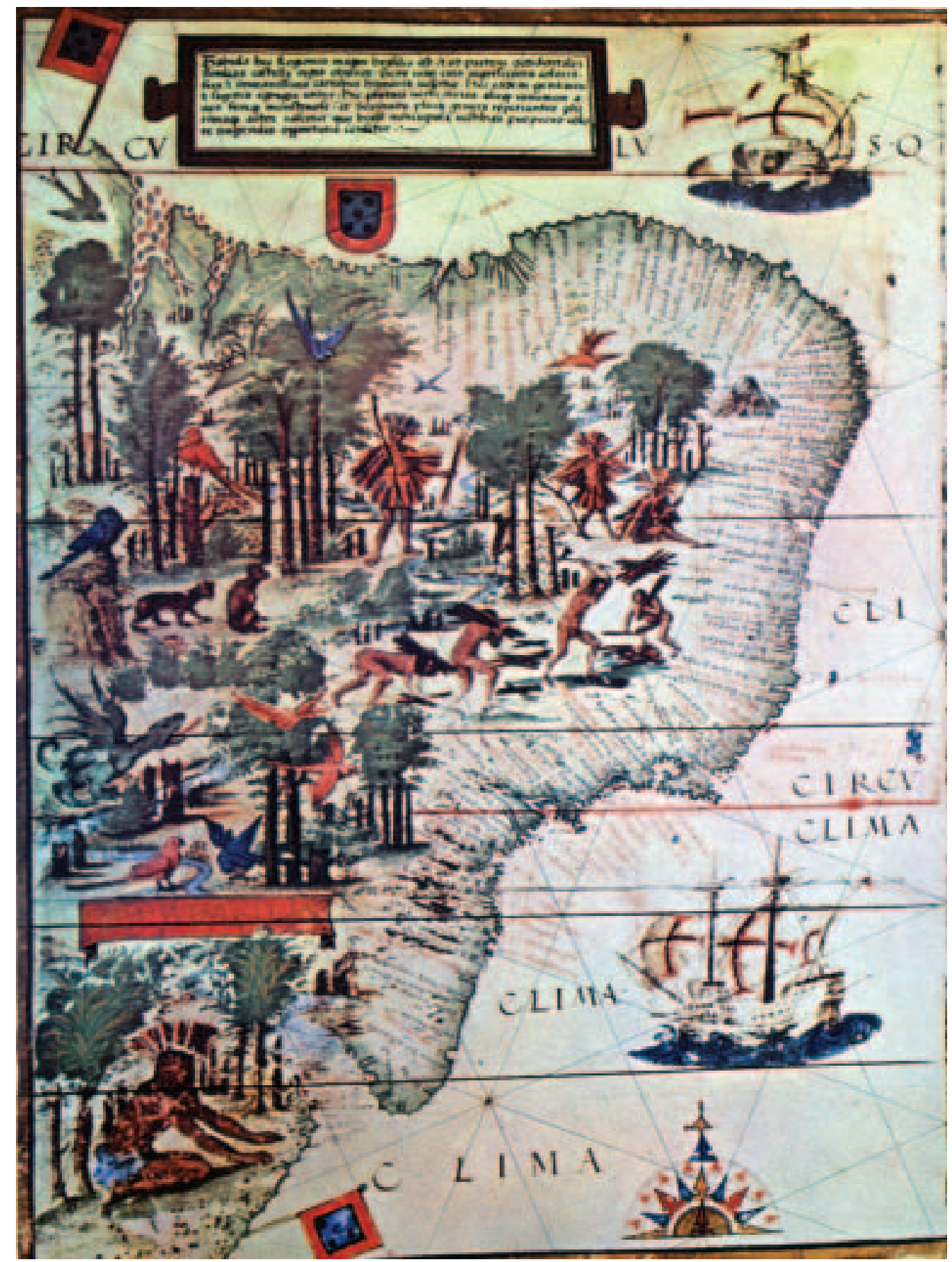

Fig .7 - Carta de Lopo Homem - Reinéis, 1519. Integra a coleção de cartas intitulada "Atlas de Miller", pertencente à Bibliotèque Nationale de Paris. 
Símbolos de vilas e "lugares"

village

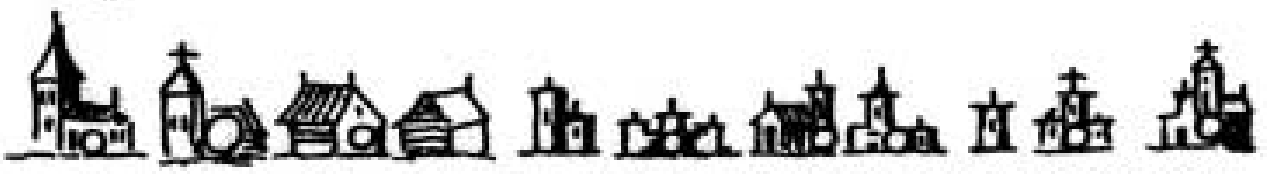

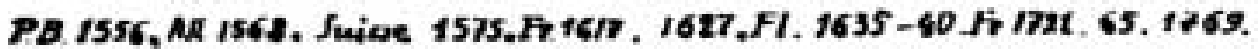
○ 0 ○ 0
○
(
00000

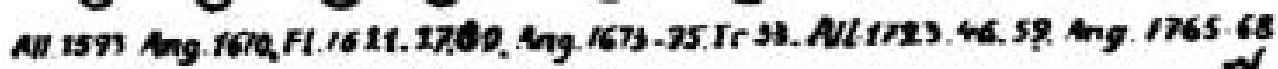
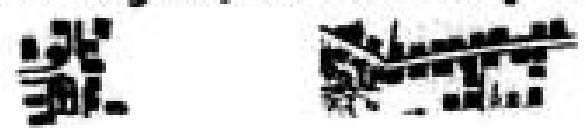

ำ $: \% \circ$

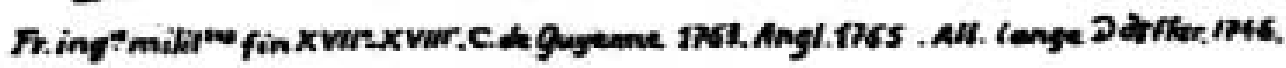

Village avec eglise. [0.
Sans
○ $\odot 000$

AII.8593. 8626.1702 .877 .1752 .

\section{Eamesu}
Q
$\triangle \Delta \quad \Omega$
d b rit.

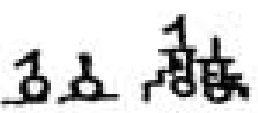

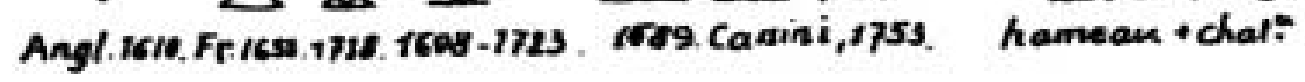

Fig. 8 - DAINVILLE, François. Le langage des géographes. Termes, signes, couleurs des cartes anciennes

1500-1800. Paris, 1964. Biblioteca da École des Hautes Études en Sciences Sociales - Paris. 
Símbolos de florestas
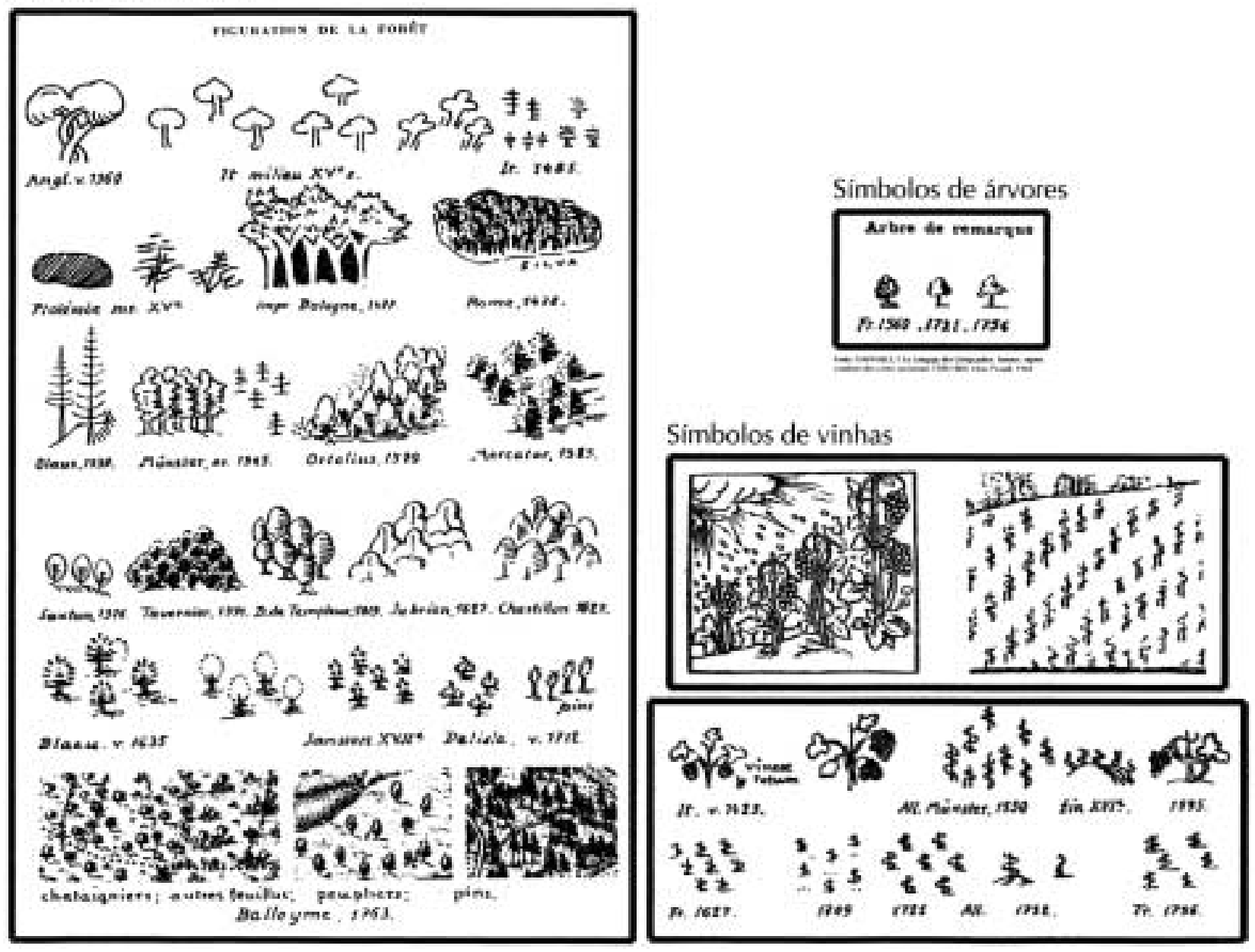

Fig. 9 - DAINVILLE, François. Le langage des géographes. Termes, signes, couleurs des cartes anciennes 1500-1800. Paris, 1964. Biblioteca da École des Hautes Études en Sciences Sociales - Paris. 
19. EHRENSVÄRD, 1987 , p. 123-146.

20. JACOB, 1992
Observamos a progressiva passagem de um tipo de representação mais naturalista para um outro cada vez mais abstrato. Os motivos foram sucessivamente convencionados, e a natureza representada por meio de pictogramas (sistema primitivo de escrita no qual as idéias são expressas por meio de figuras simbólicas), ideogramas (sinal que exprime uma idéia) e outros símbolos gráficos (tramas, variação de valor, etc.). Essa esquematização simbólica pressupôs a uniformização das convenções para que se tornassem inteligíveis nos diferentes locais culturalmente afins.

Segundo Ulla Ehrensvärd ${ }^{19}$, a partir do século XVI, a cor, como qualquer outro código, perdeu progressivamente sua função decorativa, restringindo-se à sua simples dimensão informativa. Os primeiros tratados sobre o assunto foram publicados na ltália, depois na Inglaterra, Holanda e França. Na Inglaterra entre esses tratados que se vincularam à prática dos agrimensores - responsáveis pelo levantamento e cadastramento das propriedades fundiárias locais - destacaramse o de John Norden, Surveior's Dialogue, redigido em 1607; o de A. Rathborn, The Surveyor, publicado em 1616; o de W. Cuningham, Feudigraphia e o de Leybourn, The Compleat Surveyor. Tais trabalhos são interessantes, pois apresentam uma metodologia de desenho das cartas topográficas, incluindo indicações sobre a preparação das cores, o suporte, etc. Completaram os manuais ingleses de agrimensura alguns tratados específicos sobre aquarela, publicados na França e na Inglaterra, que mesclavam questões relativas à pintura a assuntos específicos da cartografia IGAUTIER, 1687; SMITH, 1701; BUCHOTTE, 1722).

A partir do século XVIII, a cartografia perdeu definitivamente o caráter decorativo em benefício da precisão científica. Nesse contexto, acirrou-se o debate sobre a questão das cores nos mapas, reduzidas ao mínimo, restringindose apenas aos aspectos funcionais e informativos. Essa campanha em prol de um colorido purista foi amplamente encabeçada por Johann Hubner, autor do Museum geographicum, publicado em 1726, em Hamburgo. $\bigcirc$ emprego de um código pressupunha a sua estabilidade para viabilizar sua assimilação e, portanto, implicava a uniformização dos estilos. Esses tratados, entre inúmeros outros, contribuíram para tal processo.

A parte escrita dos mapas restringiu-se ao título, topônimos e legendas ${ }^{20}$. A linguagem verbal (sobretudo os topônimos) foi progressivamente substituída por signos convencionais, pictogramas e símbolos gráficos. A transição entre as cartas invadidas pela escrita (típicas do século XV e XVI) - clamando mais pela leitura que pelo olhar - por aquelas que privilegiavam a visibilidade à legibilidade, impondo ao desenho uma certa economia gráfica, foi resultante dessa longa trajetória histórica.

Em Portugal, no que diz respeito às técnicas de levantamento topográfico, corográfico e geográfico e sua respectiva representação no papel, o grande impulso renovador ocorreu no reinado de $D$. João $V$, quando foram publicados dois importantes tratados - Tratado do modo o mais facil e o mais exacto de fazer as cartas geographicas, assim de terra como de mar, e tirar as plantas das praças (1722) e O engenheiro portuguez (Tomo I, 1728/1729). 
Ambos foram elaborados pelo então engenheiro-mor do reino, Manoel de Azevedo Fortes, designado em 1720 membro da Academia Real de História e encarregado de realizar novos levantamentos geográficos das províncias do reino e conquistas ultramarinas. Foram os primeiros tratados publicados em Portugal sobre a matéria, responsáveis por uniformizar as práticas cartográficas, introduzindo normas e convenções ("regras" e "máximas"), de acordo com os modernos procedimentos, sobretudo divulgados pelos franceses.

Os tratados publicados por Azevedo Fortes foram o resultado concreto do impulso de renascimento da ciência do desenho geográfico promovido por D. João $V$ e basicamente são uma síntese dos congêneres Methode de lever les plans et les cartes de terre et de mer, avec toute sortes d'instrumens, \& sans instrumens, de Jacques Ozamam (1693); L'ingénieur français, provavelmente de Naudin (1696); Les elemens d'Euclides, de R. P. Dechalles; Demontrez d'une maniere nouvelle \& facile, de M. Ozanam; e Les règles du dessein et du lavis, de Buchotte (1722). A novidade dos seus tratados residiu na didática com que expôs o método mais prático de proceder aos levantamentos de campo e à maneira de transpô-los para o papel, fruto da sua experiência pessoal e da síntese dos manuais franceses citados.

levantamento de campo

formato de livro de bolso do Tratado do modo o mais facil, e o mais exacto de fazer as cartas geograficas, assim da terra, como do mar, e tirar as plantas das praças, cidades, e edificios com instrumentos, e sem instrumentos, para servir de instrucçam a fabrica das cartas geograficas da historia ecclesiastica, e secular de Portugal (1722), de Manoel de Azevedo Fortes, correspondia ao propósito de estar sempre à mão, em pleno trabalho de campo.

Até o fim do século XVIII, o engenheiro ao sair a campo, acompanhado de dois ou três ajudantes que soubessem medir e do(s) "picador(es) de mato", deveria levar os seguintes instrumentos: prancheta circular moderna; pedômetro; bússola; meias balizas com bandeirolas; corda ou corrente de ferro delgada ${ }^{21}$ ("cadeia"); tábua delgada do tamanho e feitio de meia folha de papel para escrever e riscar em campo os "borrões" (esboços); "o borrador ou caderno de lembrança"; lápis; "estojo de mathematica"; petipé ${ }^{22}$; duas réguas de pinho ${ }^{23}$ de 1,5 m e $6 \mathrm{~m}$ e barracas para abrigar a comitiva.

No tratado $O$ engenheiro portuguez (1728/1729), Azevedo Fortes é bastante minucioso na descrição do funcionamento dos aparatos empregados nos levantamentos de campo, ilustrados na estampa 7, do tomo I (Figura 10). $\bigcirc$ antigo teodolito, então chamado de prancheta graduada, prancheta universal ou prancheta circular moderna por Jacques Ozaman, matemático da Universidade de Paris, era uma circunferência graduada sobre um tripé, dotada de um óculo fixo (BB) e outro móvel (CC) sobre uma régua, na qual estava presa uma pequena bússola destinada a orientar o levantamento. Tal descrição era semelhante à do
21. Menos recomendada, pois tendia a embarrigar quando muito comprida, tornando a medição menos exata.

22. O petipé (i.e. pequeno pé), tal como alcunhado pelos franceses, era a escala gráfica da época, orientadora das medidas e relações de proporção presentes nos mapas. Era gravado em régua de latão, madeira ou pergaminho, com medidas em léguas, braças, pés, palmos e polegadas.

23."as regoas, que servem as mediçoens sobre o terreno, se fazem ordinariamente de pinho, por ser madeira mais leve, e saõ necessarias duas aos medidores: huma de sinco palmos de craveira, e outra de vinte, e os palmos de cada huma devem ser todos notados com hum sinal feito com serra delgada; porque os de tinta se apagão facilmente [...]". Cf. FORTES, 1728/1729, tomo I, p. 324. Convém mencionar que o palmo craveiro correspondia a $30,5 \mathrm{~cm}$, em Portugal. 
24. Sobre o modo de proceder, Fortes nos dá um exemplo bastante elucidativo: querendo tomar as posições de alguns lugares, por exemplo, ao redor de Lisboa, deve-se tomar base num ponto de observação cuja distância é conhecida em rela ção ao $2^{\circ}$ ponto de observação (como a distância da torre do Loreto ao Castelo). Posicionado no $1^{\circ}$ ponto de observação (a torre) mirava-se com óculo fixo o Castelo e com o óculo móvel procedia-se, com muito cui dado, à tomada dos luga res escolhidos, como por exemplo, Almada, Lavra dio e Palmela, lançando simultaneamente os da dos sobre o papel. Passando com o instrumento ao Castelo, iniciava-se novo levantamento conforme o método supracitado desta vez mirando com o óculo fixo a torre do Lo reto (na qual se deixava uma bandeirola) e com o óculo móvel a posição e ângulo dos demais pon tos escolhidos (Almada Palmela e Lavradio). Estas linhas cruzando-se às primeiras determinavam as posições dos lugares levantados, cuja distância entre eles podia ser estimada através de cálculos trigonométricos. A prancheta circular modern também se prestava para a demarcação de linhas retas, no terreno.

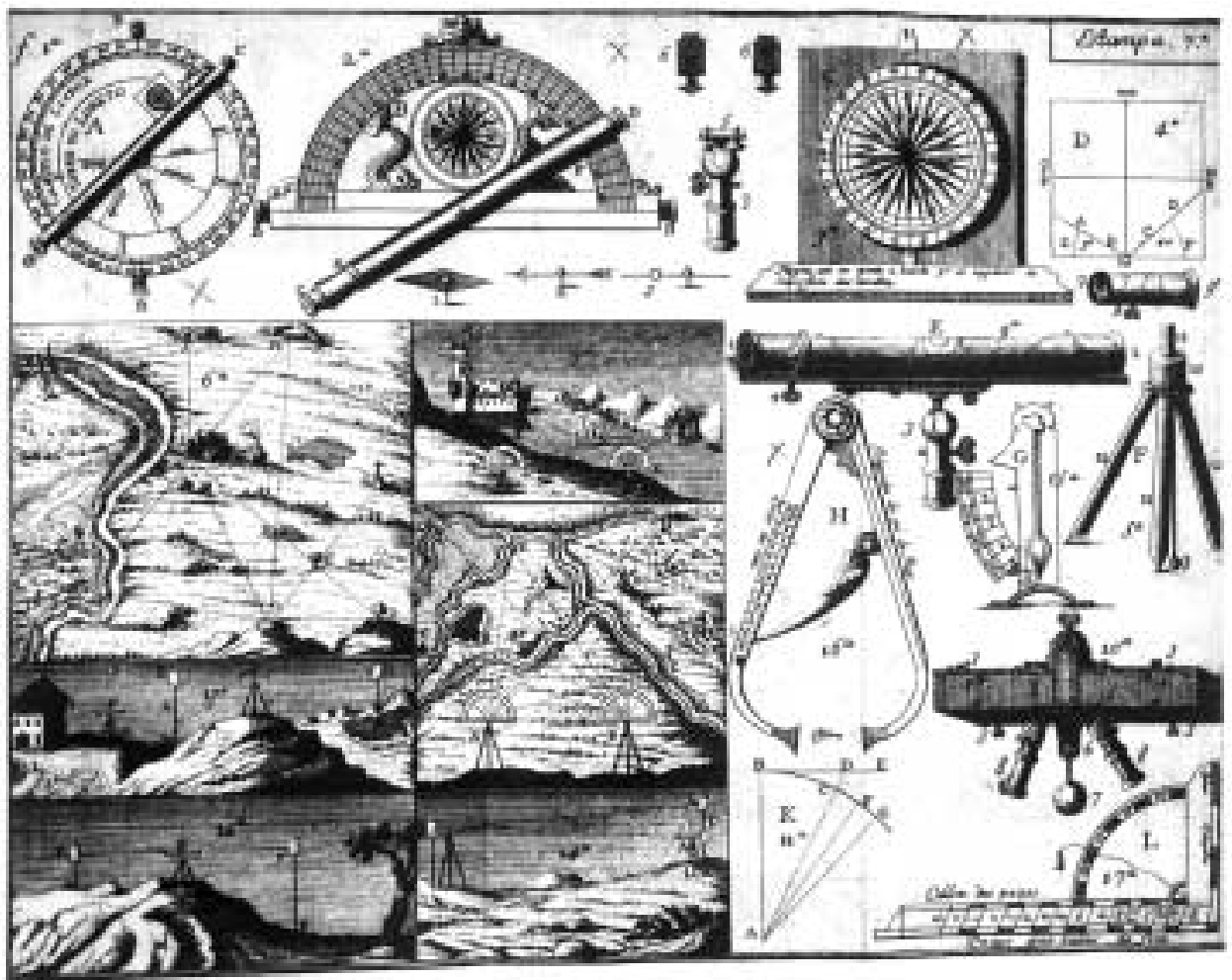

Fig. 10 - FORTES, Manoel de Azevedo Fortes. O Engenheiro Portuguez. Lisboa: Na Officina de Manoel Fernandes da Costa, 1728/1729, Estampa n.7. Biblioteca Noronha Santos - RJ.

tratado italiano de Cósimo Bartoli (1559), segundo a qual para tomar a posição de determinados lugares bastava se posicionar em uma colina ou edifício alto, direcionando o óculo fixo do instrumento para um ponto cuja distância era conhecida e o óculo móvel para o ponto que se pretendia levantar, reproduzindo no papel a seqüência das tomadas realizadas, com as correspondentes direções dadas pela bússola e os ângulos obtidos na circunferência graduada. Por meio do sistema de triangulação e tabelas de senos e cossenos dos ângulos obtidos, calculava-se a distância entre os vários pontos observados ${ }^{24}$.

Além da prancheta circular moderna, outro instrumento era também utilizado no cálculo de distâncias inacessíveis para levantamentos topográficos. Tratava-se do pedômetro - espécie de relógio levado à cintura ou preso ao joelho, sob a calça, por meio do qual eram contadas as passadas. Embora permitisse medir grandes superfícies - cerca de 20, 30 e 50 léguas --, o instrumento era pouco preciso, servindo apenas para medições aproximadas. No caso da medição de longas distâncias, esse pequeno relógio era colocado sob a pata de um cavalo, preso à sela.

Os levantamentos também podiam ser feitos apenas com a bússola, embora ficassem menos precisos do que com a prancheta circular moderna. 
De qualquer forma, a bússola era o instrumento indicado para a tomada da curvatura dos caminhos e rios (Figura 11):

[...] primeira volta, ou cotovelo mais consideravel, que a ribeira faz; e esta linha recta assim considerada, se veraõ entre o ponto $A$, e o ponto B as voltas menos consideraveis, que vay fazendo a ribeira, da linha imaginada se lançaráõ perpendiculares fingidas, que se mediràõ, e iraõ notando, e tambem os graos, que a agulha aponta; e caminhando para o ponto B, se irà medindo a distancia $A B$, e notando: isto feito, no ponto $B$ se farà Segunda estação, e se notaràõ os graos apontados, e tudo o mais, como na primeira estaçaõ: no ponto $C$ se irà fazer terceira estação, e outra quarta estaçaõ no ponto D, se houver de continuar mais para diante. No papel, ou borrador se irà fazendo a figura de algum modo semelhante à figura, que a ribeira faz no terreno, e notando tudo (FORTES, 1722, p. 96-99).

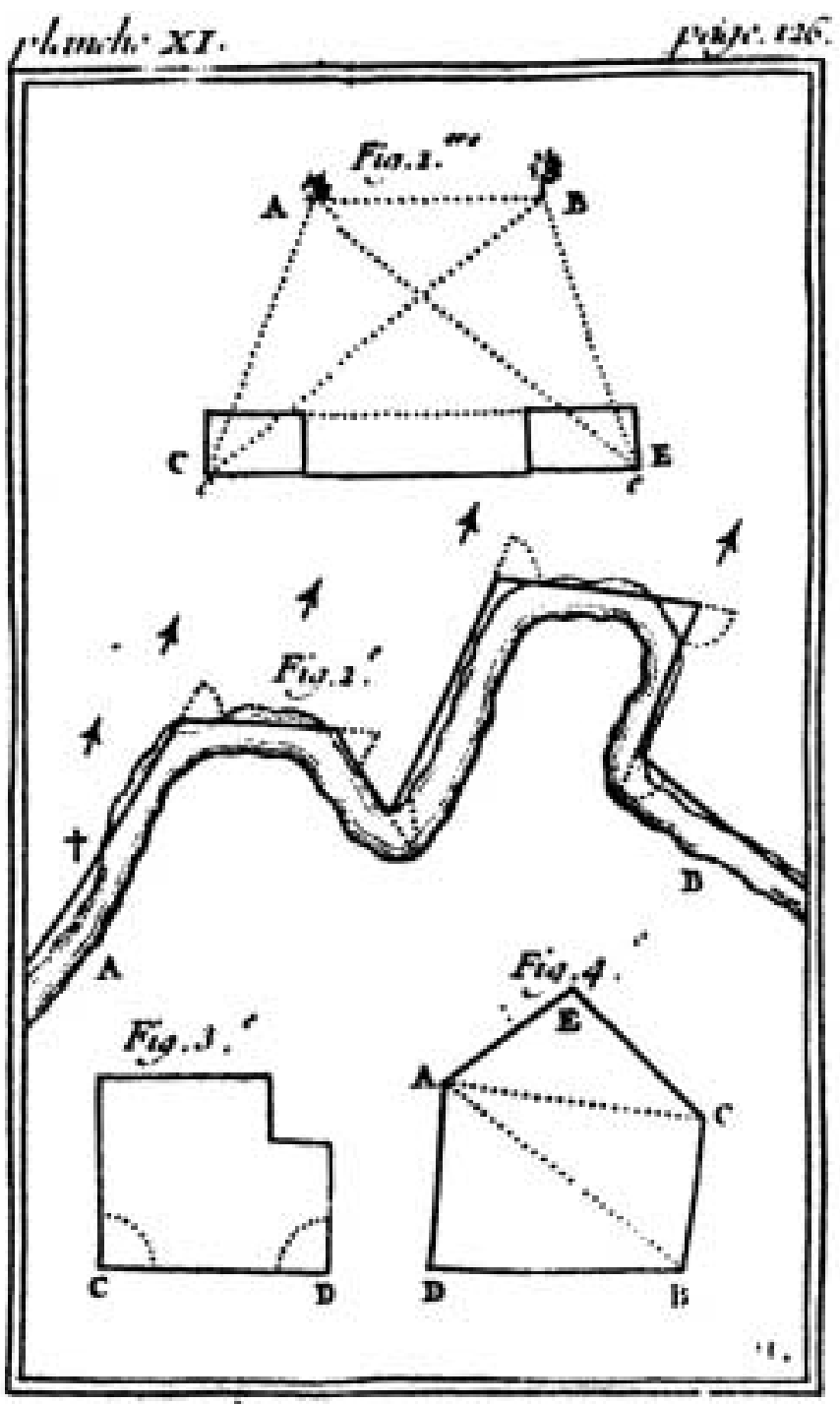

Fig. 11 -OZAMAN, Jacques. Methode de lever les plans et les cartes de terre et de mer, avec toutes sortes d'instrumens, \& sans instrumens. Nouvelle édition. A Paris: Chez Charles-Antoine Jombert, 1750. Biblioteca Nacional de Lisboa. 

e caminhos era feita com o auxílio de um transferidor (instrumento semicircular, dividido em $180^{\circ}$, transparente e próprio para a medição de ângulos).

Convocada a comitiva e reunidos os instrumentos necessários, procedia-se da seguinte forma: 1) definia-se a escala gráfica do levantamento o petipé; 2l procedia-se a algumas jornadas prévias para vistoria do terreno, com objetivo de se ter idéia dos seus montes, vales, rios, ribeiras, matos e planícies; 3) escolhiam-se os lugares altos convenientes para se assentar as "estações" de observação, deixando-lhes as balizas com bandeirolas; 4) começava-se o levantamento aleatoriamente por qualquer parte; 5) diante da dificuldade de se encontrar sítio suficientemente plano onde assentar o teodolito, o engenheiro-diretor mandava proceder ao nivelamento do terreno com um nível; 6) se a província apresentasse cordilheira intransponível, desenhavam-se apenas os contornos das suas vertentes, tal como dos rios, ribeiras, montes, lagoas ou mesmo matas fechadas; 7) as operações feitas deveriam ser transferidas todos os dias para o papel - no borrador ou caderno de lembrança, "porq em quanto està fresca a idéa daquelle sitio, tudo o que the pertence se nota melhor", sendo qualquer equívoco de medição passível de ser retificado in loco; 8) querendo desenhar a carta geral do reino, bastava ajustar os "confins" de várias cartas corográficas de províncias ou bispados, de mesmo petipé; 8) jamais se poderia esquecer de orientar o levantamento, marcando o Norte na rosa-dos-ventos (tal orientação feita com o auxílio de uma bússola ou relógio de sol era a melhor para se localizar o Norte verdadeiro).

Com base nos tratados estrangeiros, além dos símbolos gráficos e das cores, convencionou-se "nas Cameras dos Estados do Brasil" que cada légua continha três mil braças e cada 17 léguas "escassas" correspondiam a um grau da Esfera ${ }^{25}$. Em termos aproximados, "huma hora de caminho a passo cheyo, e ordinario" (FORTES, 1722, p. 4) também correspondia a uma légua. Outra convenção de representação importante, advinda do ramo dos geógrafos, dizia respeito ao posicionamento das coordenadas referentes às latitudes e longitudes:

Os geografos costumaõ nas suas cartas pôr a linha do Norte [meridiano] parallela ao lado do papel, e obrando por longitudes, \& latitudes nas cartas geraes, a base do papel he parallela ao Equador; e o lado do papel parallelo ao primeiro meridiano nas cartas de graos iguaes.

Havia tabelas impressas divulgando o posicionamento das principais cidades do reino. Todavia, no que diz respeito ao Brasil, foi preciso calcular as latitudes e longitudes de cada localidade importante in loco. Essa tarefa coube inicialmente aos jesuítas, alcunhados de "padres matemáticos" e, depois, aos engenheiros militares integrantes das expedições científico-demarcatórias.

Sobre o uso das tabelas de longitude, em Portugal, Azevedo Fortes instruiu:

Quem quizer por exemplo fazer por via das latitudes, e longitudes a Carta deste Reyno de Portugal, e Algarves, he necessario saber que o seu comprimento està incluido entre trinta e 
sete, e quarenta e dous graos de latitude, e entre nove, e doze graos de longitude; e assim o seu comprimento saõ cinco graos, e a sua largura tres.

Isto supposto, se lança huã linha, que se toma por Meridiano, e se divide em cinco partes iguaes, que representaõ os cinco graos do seu comprimento, e do extremo da linha se levanta huma perpendicular, q representa hum circulo parallelo ao equador, e distante trinta e sete graos, e pelas divisoens outras tantas linhas parallelas às primeiras.

Estas linhas parallelas se dividem nos tres graos de longitude, que comprehende Portugal: mas he necessario advertir que os graos de longitude só são iguaes aos da latitude sobre o equador, e depois vaõ diminuindo para os pólos; e he necessario notar esta differença, q se conhece pelas taboadas das longitudes, que andão impressas em varios Autores, e as traz o nosso Roteiro Portuguez da Navegação; a onde tambem se poderàõ ver as latitudes, e longitudes dos principaes lugares deste. [...] Estas longitudes, e latitudes se notão nas Cartas por humas linhas graduadas, que the servem de orla.

mais ordinario he que a linha graduada, que serve de base ao papel, denota as latitudes, como tambem a da cabeceira, e as linhas dos lados do papel representão as longitudes (FORTES, 1722, p. 193-195) (grifo é nosso).

Todas as informações citadas nos parecem relevantes para dar a noção das dificuldades inerentes aos levantamentos de grandes superfícies terrestres, no século XVIII, bem como das condições e possibilidades técnicas para tanto, com vistas a evitar considerações ou juízos anacrônicos. A exatidão presente nesses mapas era a possível naquele contexto, conforme os instrumentos e técnicas disponíveis. De qualquer maneira, além dos deliberados propósitos de distorção, o problema da longitude foi o grande responsável pela imprecisão dos mapas setecentistas, quando comparados às atuais cartas feitas por satélites.

A documentação referente às expedições científico-demarcatórias enviadas ao Brasil a partir do Tratado de Madri (1750) comprova a adoção do método astronômico inventado por Galileu. No ofício datado de 14/7/175526, do governador do Estado do Grão-Pará e Maranhão - Francisco Xavier de Mendonça Furtado - ao irmão e secretário de Estado dos Negócios do Reino - Sebastião José de Carvalho e Mello -, são apresentadas as observações realizadas pelos padres matemáticos, João Angelo Brunelli e lgnácio Semartoni:

[...] Meu Irmaõ do meu Coraçaõ: Os Pes. Mathematicos me deram conta das observações $q^{\prime}$ athé agora tem feito, na forma que a $V$. Exa. constará pelos mesmos originaes que remeto. Juntamente me deram a Relaçaõ q' taõ bem remo. de alguns instrumentos $q^{\prime}$ me dizem saõ sumamente precizos, principalmente o teliscopo para observaçaõ dos satelites, porque me dizem que para este menisterio, naõ tem mais do que hu' de q' via o P. Samarton, e q $q^{\text {to }}$ ao quadrante pequeno, me paresse que se o houver se faz muito precizo porq' á excepçaõ de hu' de que via o mesmo P., saõ os outros taõ grandes, que para andarem em huã canoa, e sahirem della a fazerem-se as observações, será huã couza sumam ${ }^{\text {te }}$ difficultoza, porq' na verdae. tem tem huã grandeza desproporcionada, e se os Pes. q' vieram do Sul deixaram os seus instrum ${ }^{\text {tos }}$ em Lxa [Lisboa] algu' quadrante havia de vir dos pequenos, e esse mesmo pode servir, e qdo naõ viessem tenham paciencia, e remedeem-se, como poderem com os grandes, porem no q'respta. ao telescopo se aparecer ahi será mo bom que venha. Deos gde a V. Exa. Arrayal de Mariuá 14 de julho de 1755.
26. Arquivo Histórico U1tramarino-ACL-CU-020, cx.1, D. 36. Rio Negro. 
27.Arquivo Histórico Ul tramarino, cx. 737 (14).

28. Coleção Pombalina da Biblioteca Nacional de Lisboa, n. 627, f. 72 .

29. Convém um breve esclarecimento sobre essa literatura. Simultaneamente aos importantes levantamentos cartográficos realizados pelos Cas sini e sua equipe na França, a Académie Royale des Sciences enviou duas missões ao Equador e ao Círculo Polar para medir in loco os graus das latitudes, com vistas a colocar um ponto final na querela sobre o formato da Terra.A primeira a partir fo a Missão do Peru (1735 1744) que envolveu três acadêmicos - Godin, Bouguer e La Condamine. A segunda, chamada Missão do Norte (1736-1737), fo integrada por Maupertuis, Clairaut, Camus, Le Monnier e os resultados obtidos contradisseram os dados sistematizados a partir das observações astronômicas feitas no Observatório de Paris, apontando uma Terra não elíptica, mas achatada nos pó los, implicando portanto a revisão dos levantamentos realizados até então. Por sua vez, Jacques Ozaman era professor de matemática na Universidade de Paris e inventor da prancheta universal, instrumento semelhante à prancheta graduada ou prancheta circular moderna, bem como responsável, no século XVII, pela difusão de uma trigonometria prática aplicada aos levantamentos topográficos.
II

Longitudes astronomicamente determinadas

Pelo eclipse da Lua sucedido aos doze de Outubro de mil sete centos cinquenta e trez, e de algums satellites de Jupiter, achei pello calculo a longitude da cidade do Pará, 329 . graos; tomando para primeiro Meridiano a llha do Ferro; chegadas as observaçoens correspondentes de Europa, poderase determinar algums minutos de diferença com exactidão.

$[\ldots]$

Estas observaçoens foraõ feitas com huma agulha do theodolite inglez a qual tem de comprimento 5 polgadas.

$[\ldots]$

IV

Thermometros e Barometro

Pelo Thermometro Inglez [...], chamado de Fahrenheit, achei que neste clima o grao de calor entre meio dia e trez da tarde, he ordinariamente 83 the 84 graos; o mayor naõ excedeo 86, o menor naõ passou de 72 graos.

$\bigcirc$ Barometro geralmente esta na altura de 50 polgadas, nem sobe, nem jamais desce, que huma linha no Parà.

Em Mariva achei a mais grande altura 29 polgadas e 97/100 de huma polgada; a menor foy 29 polgadas e 74/100.

Em estas observaçoens e calculos me servio de companheiro e me ajudou Enrique Wilckens.

Ignacio Semartoni da Compa. Jesus.

No fim da carta, encontra-se listada a encomenda dos instrumentos necessários: três telescópios para observação dos satélites de Júpiter, dois quadrantes pequenos para medição da altura do Sol nos cálculos da latitude e três relógios de pêndula l" 3 óculos de 20 thé 30 palmos; 2 quadrantes piquenos inglezes de hum pé de raio pouco mais e menos; 3 relogios de pendurar").

A carta datada de 8/10/1753, endereçada a Francisco Xavier de Mendonça Furtado, acusou encomenda anterior feita pelos mesmos jesuítas, indicando a chegada de instrumentos e livros de geografia ${ }^{27}$. Outro documento ${ }^{28}$, datado de 1/12/1754, apresentou uma "relação do que se entregou aos engenheiros Galuzzi e Rebello", incluindo dois tomos das obras de La Condamine, um Tratado de Limites (versão do Tratado de Madri, 1750), as Ephemérides, de La Laille, e a Trigonometria, de Ozaman. Esses dois engenheiros integraram a expedição científico-demarcatória destinada ao mapeamento do Norte do Brasil e, certamente, essa foi a literatura ${ }^{29}$ adotada pelos membros das comissões.

desenho de gabinete: riscar e dar as aguadas

Uma vez esboçados num "borrão" (rascunho) pelo engenheiro-diretor ou engenheiro-chefe da expedição, os registros eram passados a limpo por um 
engenheiro desenhador, com especial talento para a tarefa. Passava-se então do levantamento de campo ao desenho de gabinete.

30. Cf. ÁVILA, 1996, p. 209-213.

Os instrumentos utilizados no gabinete integravam o chamado "estojo de mathematica" (Figura 12), a saber: 1) quatro tipos de régua de latão ou madeira; 2) esquadro; 3) compassos (dois simples e cinco complexos); 4) transferidor (semicírculo graduado de $180^{\circ}$ de latão ou prata); 5) petipé.

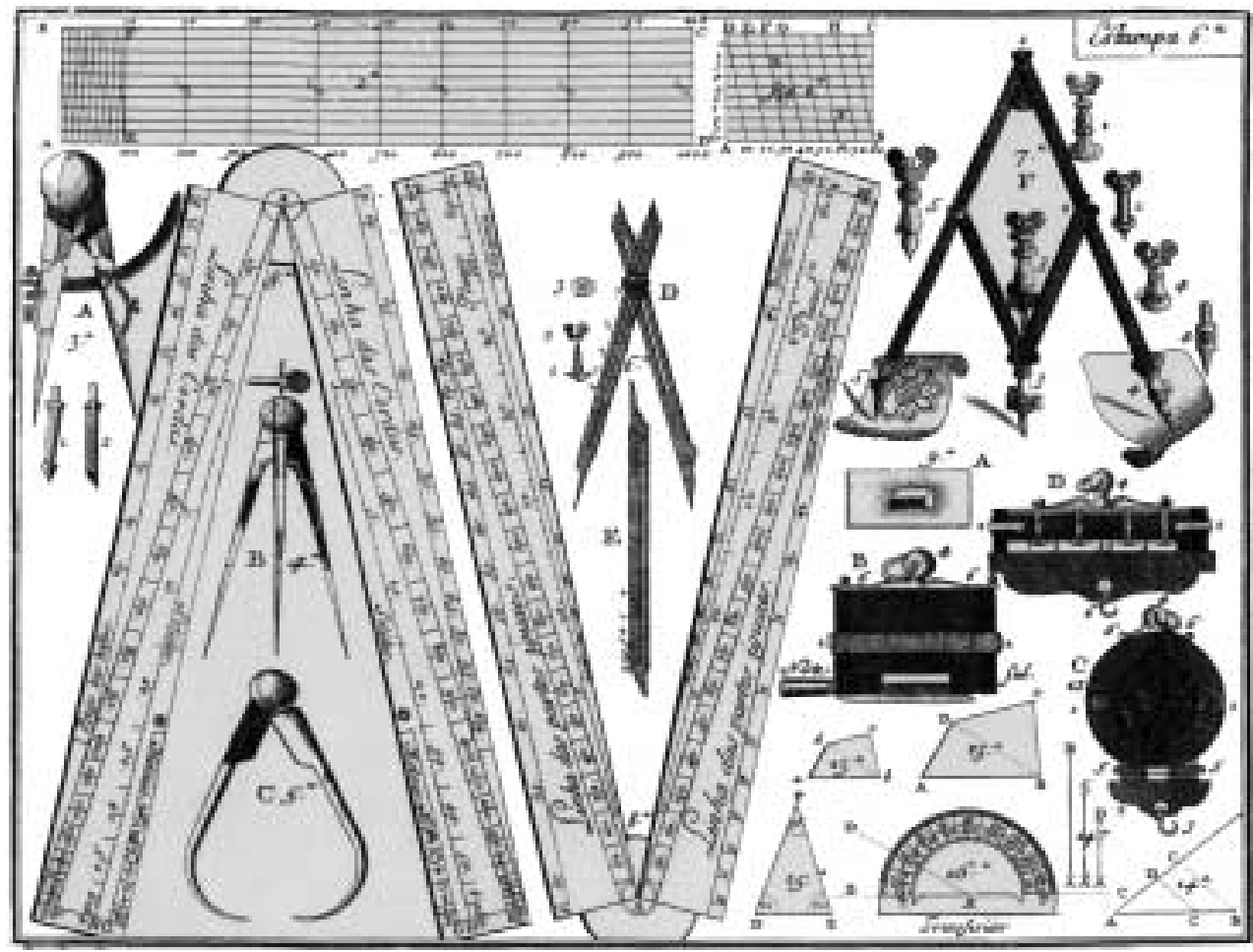

Fig. 12 - FORTES, Manoel de Azevedo Fortes. O Engenheiro Portuguez. Lisboa: Na Officina de Manoel Fernandes da Costa, 1728/1729, Estampa n. 6. Biblioteca Noronha Santos - RJ.

petipé ou escala gráfica variava de acordo com o objeto registrado. Os petipés não eram feitos arbitrariamente, cabendo aos engenheiros desenhadores respeitarem algumas convenções. Ao representá-lo nas plantas, em geral, faziam-no com duas linhas paralelas, notando-se alternadamente suas divisões internas. As medidas ${ }^{30}$ oscilavam de um lugar a outro, sendo por exemplo o pé português diferente do pé milanês e assim sucessivamente. Até a Revolução Francesa, quando foi criado o sistema métrico-decimal, houve uma estreita analogia entre as medidas e o corpo humano - polegadas, palmos, pés, côvados, passos, varas, braças e léguas -, cujas equivalências apresentamos no quadro a seguir: 


\begin{tabular}{|l|l|}
\hline \multicolumn{1}{|c|}{ Valor de medida antigo } & \multicolumn{1}{c|}{$\begin{array}{c}\text { Valor equivalente no } \\
\text { sistema métrico decimal }\end{array}$} \\
\hline 1 polegada $=12$ linhas ou 144 pontos & 1 polegada $=2,54 \mathrm{~cm}$ \\
\hline 8 polegadas $=1$ palmo & $\begin{array}{l}1 \text { palmo }=22 \mathrm{~cm} \\
1 \text { palmo craveiro }=30,5 \mathrm{~cm}\end{array}$ \\
\hline 12 polegadas $=1$ pé $=1,5$ palmo & 1 pé $=33 \mathrm{~cm}$ \\
\hline 24 polegadas $=1$ côvado $=2$ pés $=3$ palmos & 1 côvado $=68 \mathrm{~cm}$ \\
\hline 30 polegadas $=1$ passo ordinário $=2,5$ pés & 1 passo ordinário $=82,5 \mathrm{~cm}$ \\
\hline 40 polegadas $=1$ vara $=5$ palmos & 1 vara $=1,10 \mathrm{~m}$ \\
\hline $\begin{array}{l}60 \text { polegadas }=1 \text { passo geométrico }= \\
2 \text { passos ordinários }=5 \text { pés }\end{array}$ & 1 passo geométrico $=1,65 \mathrm{~m}$ \\
\hline $\begin{array}{l}80 \text { polegadas }=1 \text { braça }=10 \text { palmos }= \\
2 \text { varas }\end{array}$ & 1 braça $=2,20 \mathrm{~m}$ \\
\hline $\begin{array}{l}240.000 \text { polegadas }=1 \text { légua de sesmaria } \\
\text { ou } 3000 \text { braças }\end{array}$ & $\begin{array}{l}1 \text { légua de sesmaria }=6600 \mathrm{~m} \\
1 \text { braça quadrada }=3,052 \mathrm{~m}^{2}\end{array}$ \\
\hline
\end{tabular}

Além dos instrumentos do "estojo de mathematica", os engenheiros desenhadores dispunham de um estojo de desenho (Figura 13), contendo penas, bons canivetes para apará-las, pincéis, lápis, miolo de pão e "cola de Inglaterra".

Algumas curiosidades nos chamam a atenção. Além do miolo de pão usado para apagar os riscos a lápis, não deixa de ser hilariante o alerta de Azevedo Fortes sobre a especificidade de determinadas penas: "as de corvo saõ proprias para o dessenho de linhas extremamente delgadas, e das ordinarias as da aza esquerda saõ melhores, que as da aza direita" (FORTES, 1729, tomo I, p. 420).

Quanto ao papel, sabemos que, no século XVI, era proveniente da Itália, sobretudo fabricado em Fabriano; no XVIII os melhores eram os da França e, em segundo lugar, os da Holanda. Se colocarmos uma folha contra a luz é possível visualizar a sua marca-d'água, indicativa da sua procedência. Num breve exame feito em 26 desenhos do Arquivo Histórico Ultramarino, em Lisboa, verificamos a predominância de marcas-d'água holandesas em originais do século XVIII. As tipologias dessas marcas-d'água eram variadas e pudemos localizar algumas no livro Watermarks mainly of the 17th and 18th centuries, de Edward Heawood, "Librarian emeritus of the royal geographical society of London."

Para desenhar era necessária uma mesa firme e lisa, dotada de uma barra de madeira nas suas bordas que impedia o desenhista de encostar e amassar o papel:

e sendo a planta grande, que naõ caiba na meza se deve por o papel, de sorte que o Dessenhador the naõ encoste o peito quando dessenha; e porque tambem naõ póde deixar 


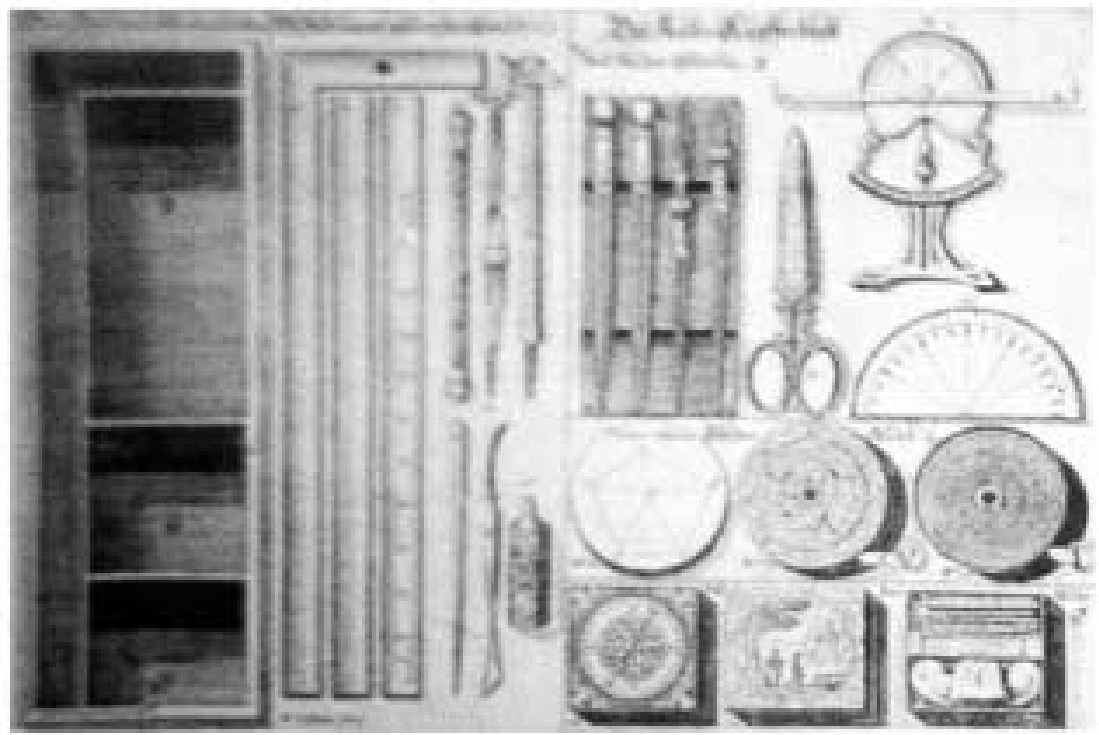

Fig. 13 - Instrumentos de medição e desenho. Autor: R. Custodis, 1644. Fonte: ADONIAS, I. Mapa: imagens da formação territorial brasileira. Rio de Janeiro: Fundação Odebrecht, 1993, p. 122.

de encostar o peito, se procurará hum sarrafo de madeira do comprimento da meza, com dous chapuzes, e dous parafuzos, para o Dessenhador poder encostar o peito, sem offender o papel, que passa por entre o sarrafo, e a meza (FORTES, 1728/1729, tomo I, p. 421).

Algumas advertências específicas orientavam 0 risco e o aquarelamento - as aguadas - nos mapas. No que diz respeito à localização da mesa no gabinete, era fundamental que estivesse posicionada junto de uma janela, recebendo a luz pela esquerda ou pela frente, nunca pela direita, em função da convenção cartográfica que estabelecia que a luz procedia da esquerda, e as sombras tombavam para a direita.

Uma vez esboçado o levantamento num caderno de notas ("o borrador ou caderno de lembrança"), no gabinete cabia ao desenhista preparar a mesa e iniciar o risco - primeiro a lápis, em seguida a bico-de-pena e nanquim. As linhas a lápis eram posteriormente apagadas com miolo de pão ${ }^{31}$. Convém mencionar que o "borrão" era feito sobre uma trama ortogonal que balizava futuras ampliações ou reduções do desenho. Essa trama-base era depois apagada com miolo de pão, mas até hoje a incisão do lápis encontra-se visível em muitos dos mapas.

Ao contrário do desenho fruto da pura contemplação, os mapas dos engenheiros militares atendiam a finalidades específicas. Sendo impossível representar de forma naturalista grandes superfícies terrestres, foi necessário desenvolver um sistema de códigos para viabilizar o entendimento daquilo que interessava ressaltar. $\bigcirc$ tratado $\bigcirc$ engenheiro portuguez (1728/1729), de 
Manoel de Azevedo Fortes, difundiu e uniformizou as seguintes convenções e códigos de representação cartográfica, em Portugal (Figura 14):

Quando o Principe manda tirar a planta de huma Praça, para por ella se poder fazer juizo da sua força, segundo o terreno, que occupa com as suas obras, e - que tem arroda do seu recinto em distancia dos tiros de Artilharia; alem do dessenho da Praça até a explanada, deve o Engenheiro Dessenhador configurar tambem o terreno, e nisto mostra mais a sua habelidade; porque the he necessario mostrar os montes, os outeiros, ov emminencias do terreno, os valles, os arvoredos, as vinhas, as hortas, os casaes, que houver, os caminhos, as quebradas, as ravinas, as pedreiras, os moinhos de agoa, ou de vento, as terras lavradas \&c., e tudo o referido, e o mais que se achar, deve ser configurado em suas justas distancias, e posições.

A Estampa decima poderá servir de exemplo; porque mostra parte do terreno do recinto de huma Praça, no qual se observará o modo com que cada huma destas cousas se lava; e ainda que na Estampa se naõ póde conhecer a differença das cores, naõ deixará esta de servir de norma aos principiantes, copiando-a com a circunstancia da maior, ou menor grossura, das linhas, riscadas da tinta competente, e depois dando-the as aguadas segundo as regras.

Feita pelo Engenheiro Director a planta de huma Praça, e seu terreno arroda, com tudo o que contèm em risco, costuma este entregalla ao seu Dessenhador

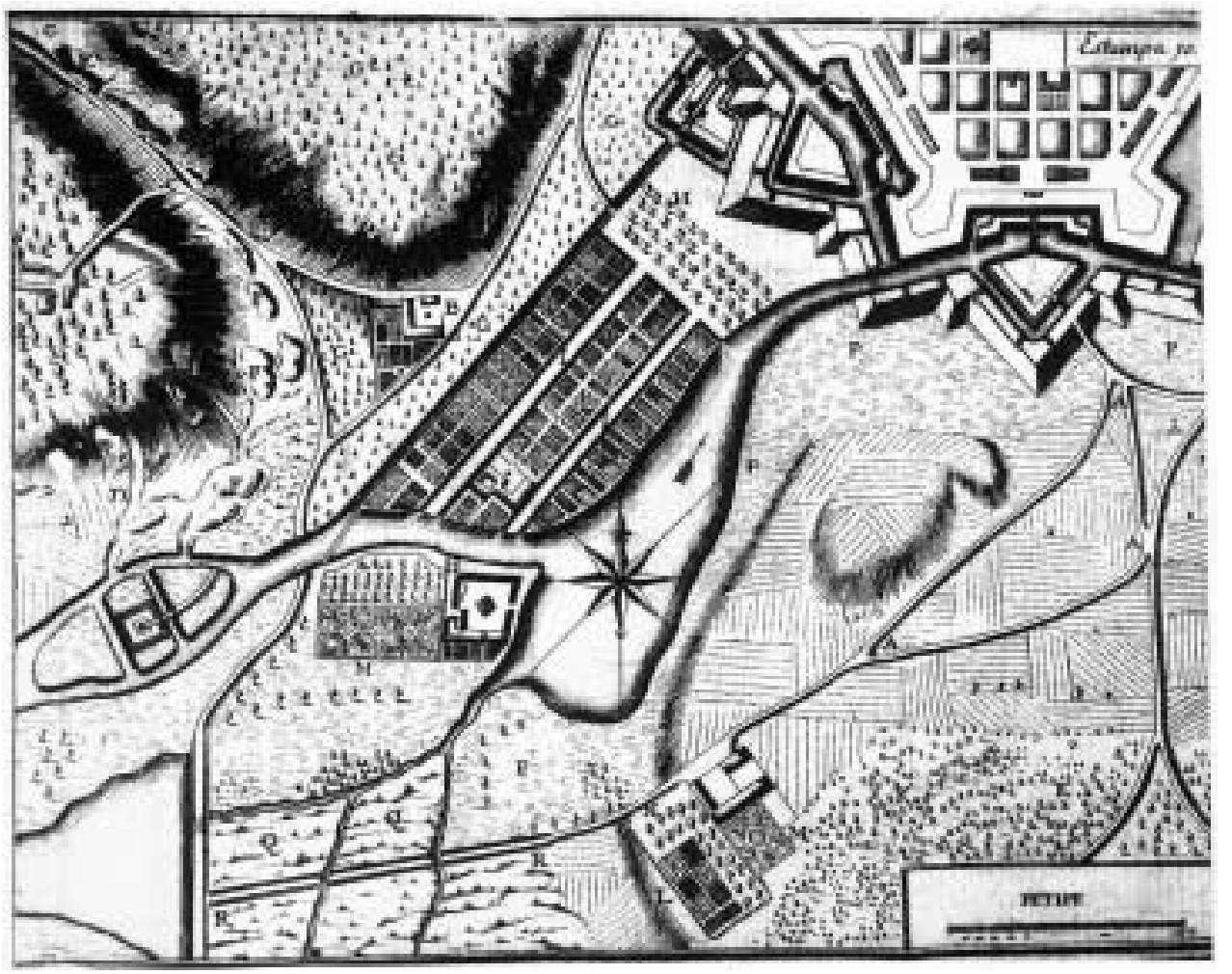

Fig. 14 - FORTES, Manoel de Azevedo Fortes. O Engenheiro Portuguez. Lisboa: Na Officina de Manoel Fernandes da Costa, 1728/1729, Estampa n. 10. Biblioteca Noronha Santos - RJ. 
para a pór em limpo, o que fará primeiramente riscando o Corpo da Praça, e rezervando para o fim as aguadas, principalmente as de carmim, e logo passará a riscar tudo o que pertence à configuração, primeiro com lapis, e depois com as tintas, e no fim se darão as aguadas a toda a planta, observando para cada especie das cousas representadas, o que se segue nos titulos seguintes.

\section{Dos caminhos}

A Primeira cousa, que se deve riscar na configuraçaõ dos terrenos saõ os caminhos, que começaõ no parapeito da estrada cuberta, e se dividem para varias partes; estes se riscaõ com duas linhas quasi parallelas de tinta da China sobre clara, e depois se the dá huma aguada, ou sombra cortada de meia tinta da China da parte de fóra do risco opposto à luz, ficando o caminho, da cor do papel.

\section{Dos montes}

Os montes, e serranias se configuraõ comhuma penna bem delgada molhada em tinta da China sobre clara, e o penejado hirá imitando a volta, que os montes fazem; e este penejado he mais, ou menos comprido, segundo he mais, ou menos comprida a escarpa dos montes, e a aguada tambem à proporçaõ mais, ou menos clara, observando a parte da luz; e naõ devem ser os riscos do penejado, nem todos iguaes em comprimento, nem em distancia huns de outros, mas feitos como ao descuido; e como os montes saõ representados chatos, ou em vista de passaro, o penejado naõ só deve acabar em riscos delgados para a parte da baze, mas tambem para o alto, fazendo estes ultimos mais curtos, que os primeiros. [...]

Quando os montes são mais a plumo, os riscos devem ser mais fortes, mais juntos, e mais direitos, e interrompidos, e a aguada mais carregada de tinta, mas naõ de sorte, que incubra o penejado, adoçando-a para cima, e para baixo, e havendo (como he ordinario) algumas quebradas, se devem notar em seus proprios lugares, o que depende de se ter tirado a planta do terreno bem ajustada. Se os montes tem arvoredos, olivaes, vinhas, ou terras lavradas, se the devem riscar, e lavar do modo, que logo diremos.

\section{Das ravinas, e pedreiras}

As ravinas [...] a sua figura se risca de tinta da China, e se lava de aguada de tabaco, ajudada de hum pouco de vermelhaõ, e suavizada para o meio, como nota a letra D. As pedreiras se dessenhaõ com hum penejado fino de tinta da China, e sombra da mesma tinta, ou cor de terra avermelhada (letra E) [...].

\section{Das vinhas}

As vinhas, ou sejaõ sobre montes, ladeiras, ou em terras planas, sempre se dessenhaõ da mesma sorte; porèm as aguadas se daõ primeiro do que se risquem as vinhas: as agudas [sic] se dão, parte de tinta da China sobre clara adoçada parallelamente à baze da planta, e parte com meia tinta de verde-lirio adoçada, e da mesma sorte parallela à baze da planta; e tambem a cor de terra se póde fazer com tinta da China, e vermelhaõ: depois desta aguada seca, com huma penna bem fina molhada em tinta da China, se dessenhão as vinhas com risquinhos pequenos, e tortuosos, parallelos à baze da planta, e cortados por outros perpendiculares (letras $G)[\ldots]$. 


\section{Dos pumares, olivaes e arvoredos}

Os pumares se riscaõ com arvores iguaes, e igualmente compassadas humas de outras, no que só se destinguem dos olivaes, e arvoredos, que naõ guardaõ regularidade: as letras $\mathrm{HH}$, mostraõ a fórma dos pumares: a letra I mostra hum olival; e as letras K, mostraõ a fórma dos bosques, ou arvoredos: as arvores se riscaõ de tinta da China, com penna bem delgada: o corpo da arvore he de figura ovada mas pontuda, a que se accrescenta hum pé curto com huma rabisca curta e delgada da parte opposta à luz: o corpo da arvore se lava de huma aguada de meia tinta de verde-bechiga, ou verde-lirio, e depois de da parte opposta da luz [...].

Os olivaes naõ differem dos bosques nas aguadas dos terrenos; porèm as arvores saõ maiores, e quasi equidistantes humas de outras, particularmente nas terras planas em que saõ postas a cordel, excepto nos terrenos montuosos, em que differem pouco dos bosques [...].

\section{Das terras lavradas, hortas, e jardins}

As terras lavradas se riscão de tinta da China sobre clara, com huma penna delgada, como a das vinhas com linhas rectas, mas a modo de tremidas humas mais que outras, dividindo o campo em courellas irregulares, como mostra a planta, mas naõ haõ de meter humas courellas por outras, de modo que façaõ feitio de canastra, alternando-as em hum mesmo sentido.[...]

As hortas se riscaõ com a regoa sobre o papel, sem a aguada clara dos montes, terras lavradas, a respeito da brancura, em que devem ficar os caminhos, fazendo os canteiros em paralelogramos desiguaes, ou quadrados, de sorte, que naõ affecte a regularidade dos jardins, e feitos os parallelogramos com tinta da China com a mesma penna, e tinta sobre clara se penejão, com linhas parallelas, ou inclinadas irregularmente, e do modo, que na Estampa se representa pela letra L. Isto feito se lhe dará huma aguada de verde-lirio em meia tinta adoçada para o meio dos canteiros [...]

dessenho dos jardins, quanto aos canteiros, naõ differem do dessenho das hortas, se naõ na regularidade, e semetria [...] (letra M); e querendo reprezentar algumas arvores à roda dos jardins, se dessenharaõ [...] (letra N).

\section{Dos prados, rios, ribeiras, e pantanos}

Os prados se dessenhaõ dando em toda a sua extençaõ huma aguada unida, em meia tinta sobre clara de verde-lirio; e depois com huma penna bem fina, molhada em tinta da China se daraõ varios pontos ao comprido, dous a dous, ou tres a tres parallelos à baze da planta, como mostraõ as letras $P$.

Os rios, e ribeiras se riscaõ com duas linhas de tinta da China, huma mais grossa, e outra delgada; a mais grossa da parte, que lhe naõ dá a luz, e a mais delgada da parte, que the he exposta; e para que naõ haja equivocaçaõ se deve notar, que vindo a luz da parte esquerda da planta, a mesma linha da borda da ribeira da parte esquerda he a que se deve assombrar; porque ainda que fica da parte da luz the he opposta, por causa da altura da margem do rio, ou ribeira, e a linha da outra parte fica exposta à luz.[...]

Os mares, rios, ribeiras, e lagoas se lavaõ de aguada de rios. [...]

Os pantanos se riscaõ com hum penejado fino, e interrompido por partes, e horizontalmente à baze da planta, como mostrão as letras $Q,[\ldots]$. 
Antes de iniciar o processo de aquarelamento do desenho, cabia ao engenheiro desenhador preparar as tintas. Tomando também por referência o tratado de Buchotte, Les Règles du dessein et du lavis (1722), Manoel de Azevedo Fortes ensinou sobre os pigmentos e a receita para composição das tintas:

\section{Das tintas}

As tintas de maior uso entre os Dessenhadores saõ a tinta da China, o carmim, a aguada de rios, o rohã̃, o Bistre, o verde-bechiga; o verde-lirio, o anil fino, o vermelhaõ, e a aguada de tabaco.

A tinta da China se vende em páos, ou bolinhos: he huma composição feita na China, que he só a verdadeira: tambem se contrafaz em França, e Holanda.

Para conhecer se he verdadeiramente da China se rossa em huma concha com agoa, como para fazer tinta, e se deixa secar a parte rossada: se depois disso a parte roçada fica liza e igual, he certo ser da China; porque sendo contra feita, fica suja, e escabroza.

O carmim he huma especie de pó impalpavel, e o mais carregado em cor naõ he o melhor: para the conhecer a bondade se destempera em agoa gomada em vaso vidrado, e sendo tirada fora, fica o vaso em malhas, he sinal, que naõ he dos melhores; porque para o ser deve ficar o vaso sem sinal da tinta: para dar as aguadas se deve escolher o melhor, porque para lançar linhas qualquer he soficiente.

A aguada de rios, ou verdete liquido, para ser bom deve tirar a azul celeste, e he preciza nas plantas para denotar as agoas: como esta tinta se naõ vende feita, darey aqui o modo de a fazer.

\section{Receita para agoada de rios}

Tomem-se duas onças de verdete fino, huma onça de cremortartero, e de goma arabiga [sic] tanto como a groçura de huma avelãa, e tudo redusido em po se deite em huma panella vidrada, e se ponha a ferver ao fogo brando com cousa de hum quartilho de agoa até esta diminuir a metade; e depois de fria se coe, e conserve em huma garrafinha de vidro bem tapada com cera.

rohão, ougoma-guta, he huma especie de goma amarella, que se desfaz facilmente. Esta tinta tem pouca escolha, mas grande uso nas plantas Militares.

O bistre he huma tinta de cor de madeira, e naõ tem escolha: serve nos dessenhos para lavar, ou dar aguadas nas obras de madeira, e em algumas configurações de terrenos, e alguns se servem tambem desta cor para lavar os foços secos.

Como o Bistre naõ he cor, que ordinariamente se venda, darey aqui o modo de o fazer.

\section{Receita para fazer o bistre}

Ajunte-se huma pouca de ferrugem de chaminé da mais lustroza, que se achar, e se ponha de infuzaõ em agoa sobre sinzas quentes, atè que a agoa tenha bem recebida a tintura, e esteja forte em cor; e depois se deitará em huma manga de papel pardo, feita em fórma de fonil, e suspendida com o seu recipiente por baixo se hirá filtrando pelo papel, e feito se guardarà em huma garrafinha de vidro, e este he o Bistre liquido: o que se vende no Norte he seco, e se poem o liquido em conchas ao Sol até evaporar toda a agoa, e depois para se usar se destempera, como as mais cores. 
○erde-bechiga he huma composiçaõ, que mostra hum verde escuro, e destemperada dá hum verde esmarelido, e serve para configurar os terrenos arroda das Praças, nas hortas, nos jardins \&c.

$\bigcirc$ verde lirio tambem he huma composiçaõ melhor, que o verde-bechiga, e tem o mesmo uso.

anil fino he de huma cor azul turquim escuro, e serve para dar aguadas nas ferragens.

O vermelhão fino he hum pó impalpavel, e o mais acezo em cor he o melhor: muitos usaõ delle para as aguadas em lugar de carmim, mas os mais curiozos só usaõ delle para as aguadas dos telhados; e para as configuraçoens dos terrenos.

A aguada de tabaco, he muito boa para as plantas, porque dá differentes cores pardas, e louras, segundo a quantidade de agua gomada com que se destempera. $\bigcirc$ modo com que se faz esta aguada, he o seguinte.

\section{Receita para fazer a aguada de tabaco}

Tome-se hum pedaço de tabaco de fumo do melhor, isto he, da melhor folha, e desfolhado se lave em agoa morna para largar, a parte que tras de melaço, e algumas areas imperseptiveis, e se lhe tire a tintura por infusaõ do modo, que fica dito do Bistre, e se guarde liquido \&c.

modo de usar das cores he destemperando-as em agua gomada a qual se faz de goma arabiga da mais clara, e escolhida, deitando duas oitavas em hum quartilho de agoa, e se deve guardar bem tapada, para que the naõ entre poeira. [...]

A tinta da china, o rohão, o verde-bechiga, o verde-lirio, o bistre seco em conchas, trazem comsigo a goma necessaria, e se desfazem em agoa clara. $\bigcirc$ bistre liquido, e a aguada de rios, (quando ao fazer se the naõ deita goma) se devem ajudar de agoa gomada, advertindo geralmente, que em todas as cores, ou tintas seja a goma de sorte, que naõ dè lustro no papel; e se a aguada de rios se chega a secar no vidro em que se guarda, se deve desfazer com vinagre branco; porque com agoa naõ seria facil.

\section{Modo de suprir as tintas}

Porque póde succeder faltarem algumas das tintas necessarias ao Dessenhador, darey aqui o modo com que se podem suprir por necessidade. A tinta da China se póde suprir fazendo-se de pós de escodar finos, dos que vem do Norte, desfeitos em vinagre branco, primeiro forte, e depois destemperado o vinagre com agoa bem gomada, e depois se faz em bolinhos ou pauzinhos, e se usa delles, como da tinta da China.

Orohaõ se póde suprir com açafraõ de França, que he em sevras secas, que naõ tem levado azeite.

ocre, e a sombra de Italia bem moidos no porfido, ou pedra dos pintores, supre as cores das aguadas dos terrenos.

Tambem com huma só cor se póde fazer huma planta a imitação da gravura, como se vé nas plantas estampadas, pondo-the letras, ou caracteres para denotar as differentes obras, com a sua explicaçaõ em hum dos lados da planta.

Com as mesmas tintas, de que temos falado, se pódem fazer, e suprir outras.

O rohão, e aguada de rios fazem hum verde admiravel.

A aguada de rios com verde-bechiga faz hum bom verde-gaio. 
O rohão com hum pouco de carmim faz cor de madeira para suprir o BISTRE: tambem faz cor de terra, e de area levando menos carmim, e tambem huma cor propria para dar aguadas nos foços secos.

O vermelhão com tinta da China fazem differentes cores de terra, e finalmente cada hum com as cores, que tiver póde fazer differentes experiencias, e segundo as differentes misturas, e quantidades de humas, e outras tintas the rezultaraõ differentes cores, o que naõ he inutil para a configuraçaõ dos terrenos arroda das praças, nas vinhas, montanhas, rochedos, matos \&c [...] (FORTES, 1728/1729, tomo I, p. 413-419).

Concluído o preparo das tintas, tomavam-se algumas precauções ao dispô-las na mesa, em tigelinhas e conchas:

Quando depois de riscada a planta começa a usar das tintas, sempre deve pôr papeis por baixo das conchas, ou tijelinhas, para que the naõ caia algum borraõ na planta, e sempre he mais seguro ter á planta cuberta por toda a parte com outros papeis, excepto naquella em que vay riscando, ou dando as aguadas, e deve procurar (ao menos em quanto as aguadas estiverem frescas) que as moscas se the naõ ponhaõ, porque costumaõ beber ou chupar a tinta, e deixar nodoa (FORTES, 1728/1729, tomo I, p. 447).

Uma vez preparada a mesa, dispostas as tintas em tigelinhas e conchas, separados os pincéis e broxas - em caso de grandes extensões de papel -, iniciavam-se as aguadas. Além do petipé, nas cartas geográficas, corográficas, topográficas e náuticas era obrigatória a introdução da rosa-dosventos ou da flor-de-lis, para orientação do desenho, respeitando-se a convenção de colocá-la no meio de rios ou do mar.

As inscrições, abundantes nos mapas quinhentistas e seiscentistas, tornaram-se raras nos mapas do século XVIII e circunscritas a áreas específicas, restringindo-se, a partir de então, ao título e às legendas. O título converteu-se, em definitivo, à informação adicional que preparava a compreensão do documento, explicitando sua natureza. Já a legenda invadiu o desenho como o "lugar da explicação" que, segundo Christian Jacob, desempenhava um papel complementar. Ela trazia um conjunto de informações que excediam o conteúdo do título, dizia o que não era representável ou o que exigia, de uma maneira ou de outra, tradução verbal, era o lugar onde terminava a utopia de uma linguagem visual, de simbologia gráfica imediatamente inteligível e legível por todos sem que fosse necessário recorrer à tradução verbal. A legenda oferecia ainda uma série de equivalências entre os símbolos gráficos e a linguagem ordinária, explicitando um liame que podia ser mais ou menos evidente, segundo o grau de mimetismo ou abstração do símbolo. A transição entre os desenhos invadidos pela escrita (típicos do século XV e princípio do XVI) - clamando mais pela leitura que pelo olhar - para aqueles que privilegiavam a visibilidade à legibilidade, impondo certa economia gráfica, é fruto dessa longa trajetória histórica de cerca de três séculos e meio. Assim como os títulos, melhor alocados na parte superior da carta, as legendas também gozavam de lugar próprio, à direita ou à esquerda, conforme o desenho: 
Quando he necessario explicar as cousas, que a planta contém, deve o Dessenhador procurar, que o lugar da explicação fique em hum dos lados direito, ou esquerdo; segundo - permettir o dessenho: tambem póde ficar ao pé da planta sem deffeito" (FORTES, 1728/1729, tomo II.

A padronização dos códigos de representação, encabeçada por Azevedo Fortes, é visível na série de desenhos dos engenheiros militares da geração seguinte, dentre os quais está José Custódio de Sá e Faria (Figura 15).

No que diz respeito à ornamentação, Azevedo Fortes pregava certa sobriedade. Para o enquadramento das cartas, legendas e títulos, sugeria a elaboração de "cercaduras" com linhas retas de diferentes espessuras, excluindo os tradicionais cartuchos ornamentados. No entanto, havia certa liberdade na ornamentação, desde que não comprometesse a capacidade informativa do desenho. A maioria das plantas militares portuguesas do século XVIII apresentava aplicação moderada da ornamentação, que basicamente se restringia às molduras

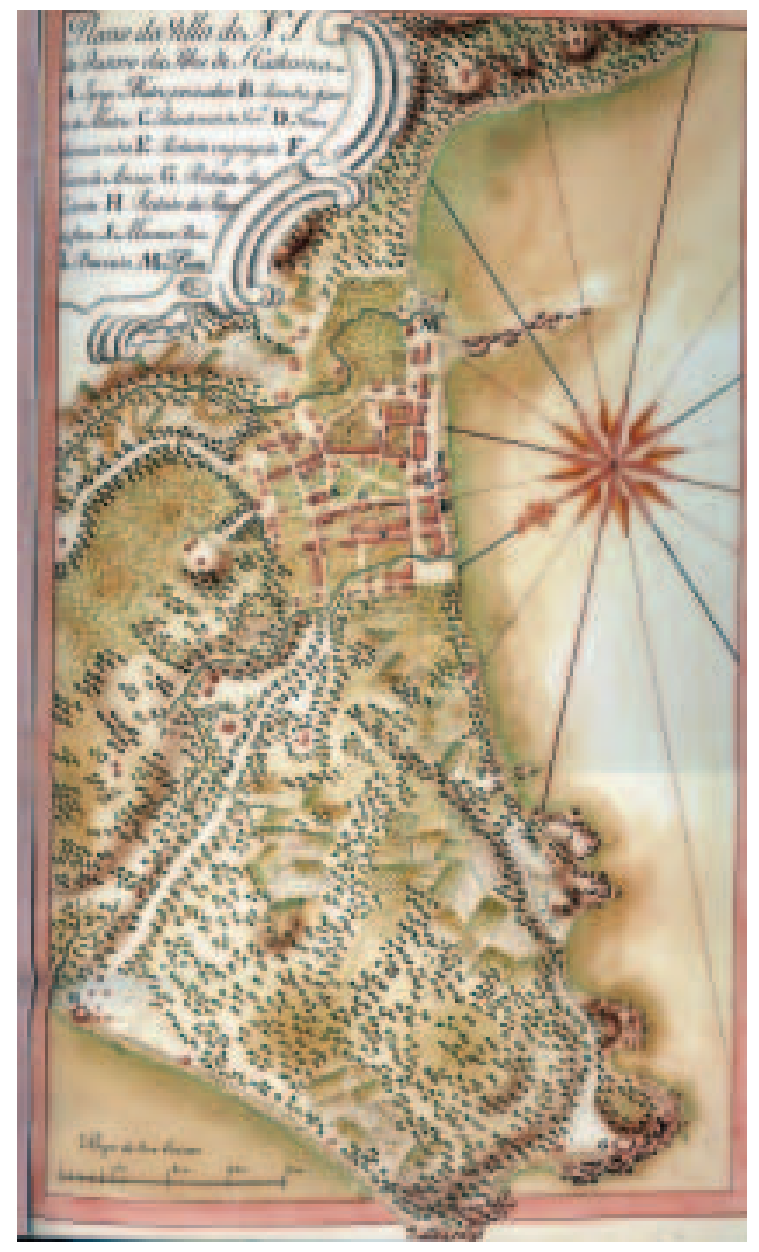

Fig. 15 - "Plano da Villa de N. S. do Desterro" [atual Florianópolis], In: SÁ E FARIA, José Custódio de. Diários e Planos do Caminho the o Passo do Rio Iguatemy, 1754. Autor: José Custódio de Sá e Faria. Biblioteca Municipal Mário de Andrade. Fonte: REIS FILHO, N. G. Imagens das vilas e cidades do Brasil Colonial. [Colaboradores Paulo Bruna e Beatriz Bueno]. São Paulo: EDUSP/FAPESP, 2000, p. 225. 
do título e das legendas. Os ornamentos empregados enquadravam-se na estética do período, havendo estreita homologia entre os cartuchos dos mapas e os motivos decorativos da arquitetura que lhe eram contemporâneos (ornatos renascentistas, barrocos e rococós).

Os cartuchos eram o local da liberdade em oposição à submissão às regras, máximas e convenções vigentes no restante do desenho. Na ausência da assinatura, o cartucho poderia fornecer os elementos necessários para se reconhecer a autoria do mapa. Esse é caso dos "prospectos" Dezenho por idea da Cidade de São Paulo (Figura 16) e Praça de Santos (Figura 17) que supomos realizados por José Custódio de Sá e Faria ou Teotônio José Juzarte. Embora não assinados, apresentam moldura com um tipo de motivo floral muito semelhante aos empregados nos frontispícios dos relatórios desses engenheiros militares. Dado que José Custódio de Sá e Faria (Figura 18) e Teotônio José Juzarte (Figura 19) foram os principais engenheiros atuantes na Capitania de São Paulo a serviço do Morgado de Mateus e tais "prospectos" estarem sediados na Biblioteca Nacional do Rio de Janeiro - parte da coleção de documentos referentes à administração desse governador (1765-1775) -, podemos inferir tratar-se de mapas feitos por algum deles.

O apêndice do Tratado do modo o mais facil, e o mais exacto de fazer as Cartas Geograficas, assim de terra, como de mar (1722), de Azevedo Fortes, também nos ensina sobre a feitura desse gênero de cartas - os "prospectos"

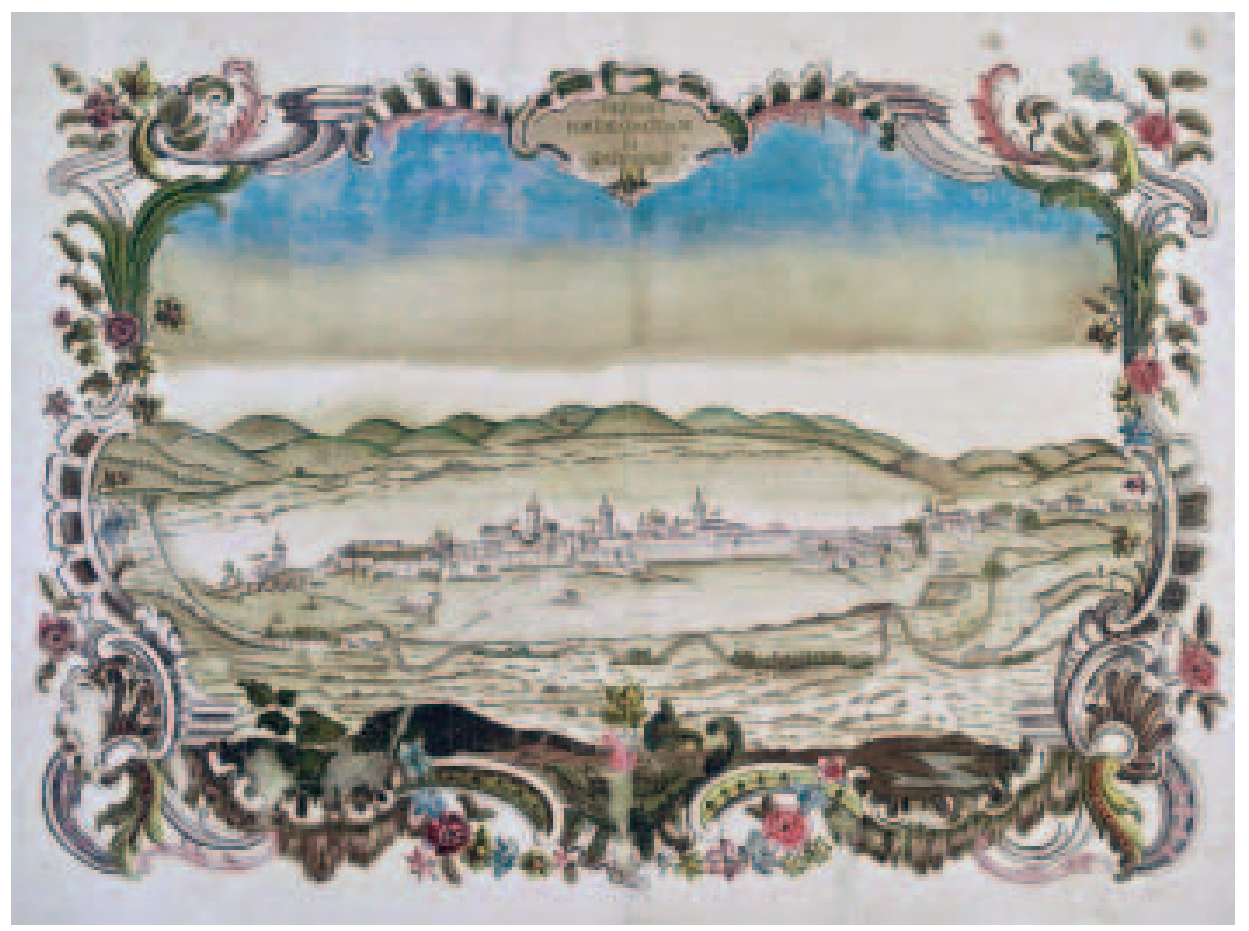

Fig. 16 - "Dezenho por idea da Cidade de São Paulo", séc. XVIII. Autor desconhecido. Fundação Biblioteca Nacional - Rio de Janeiro. 


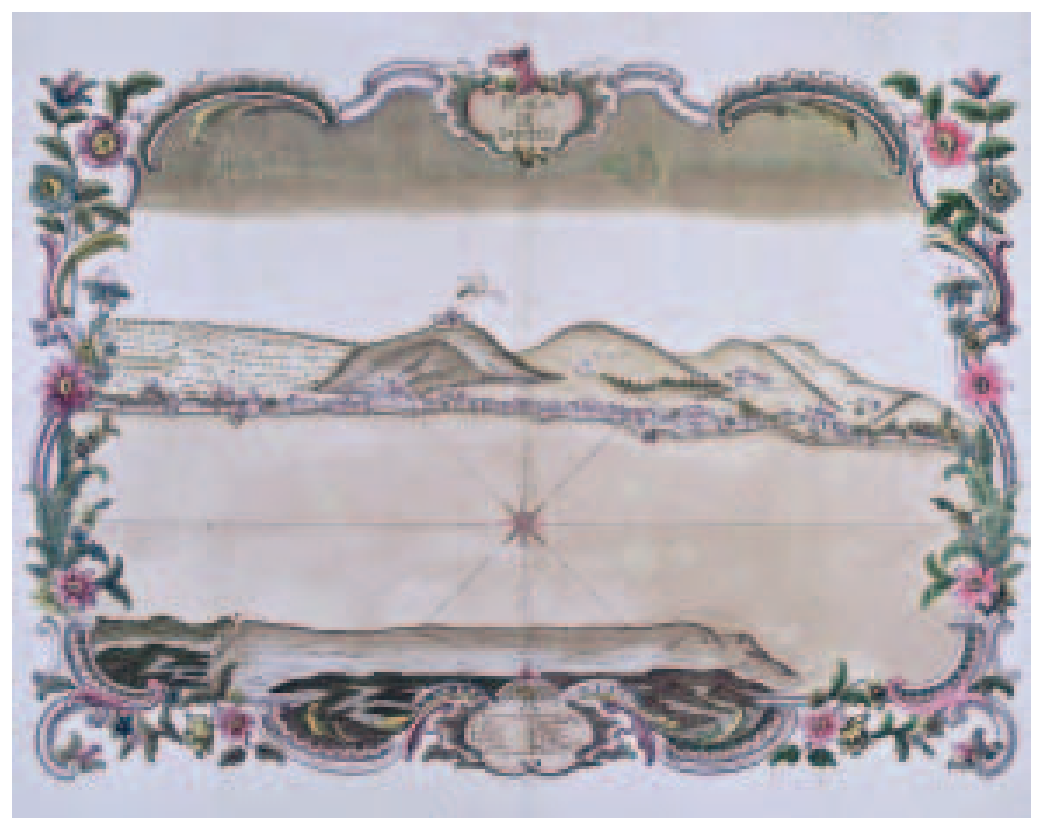

Fig. 17 - "Praça de Santos", séc. XVIII. Autor desconhecido. Fundação Biblioteca Nacional - Rio de Janeiro.

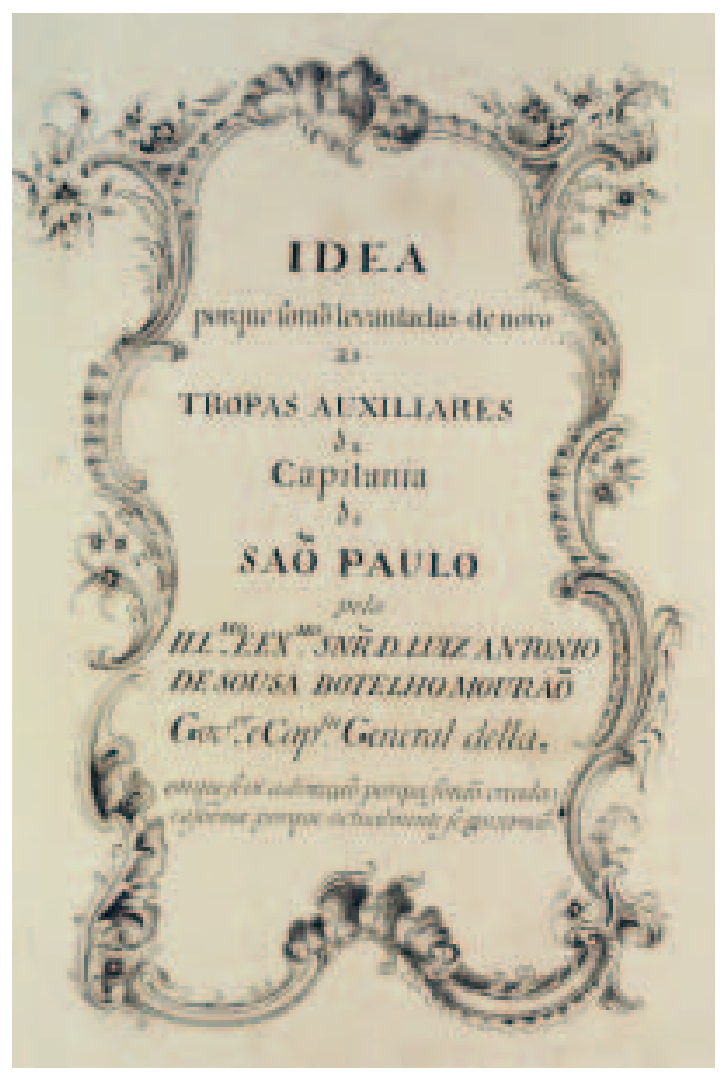

Fig. 18 - Frontispício de "ldea porque forão levantados de novo as tropas auxiliares da Capitania de São Paulo pelo IIImo e Exmo Snr. D. Luiz Antonio de Sousa Botelho Mourão Govor e Capm General della, em que se vê a direcção porque forão creadas e a forma porque actualmente se governão". Fundação Biblioteca Nacional - Rio de Janeiro. 


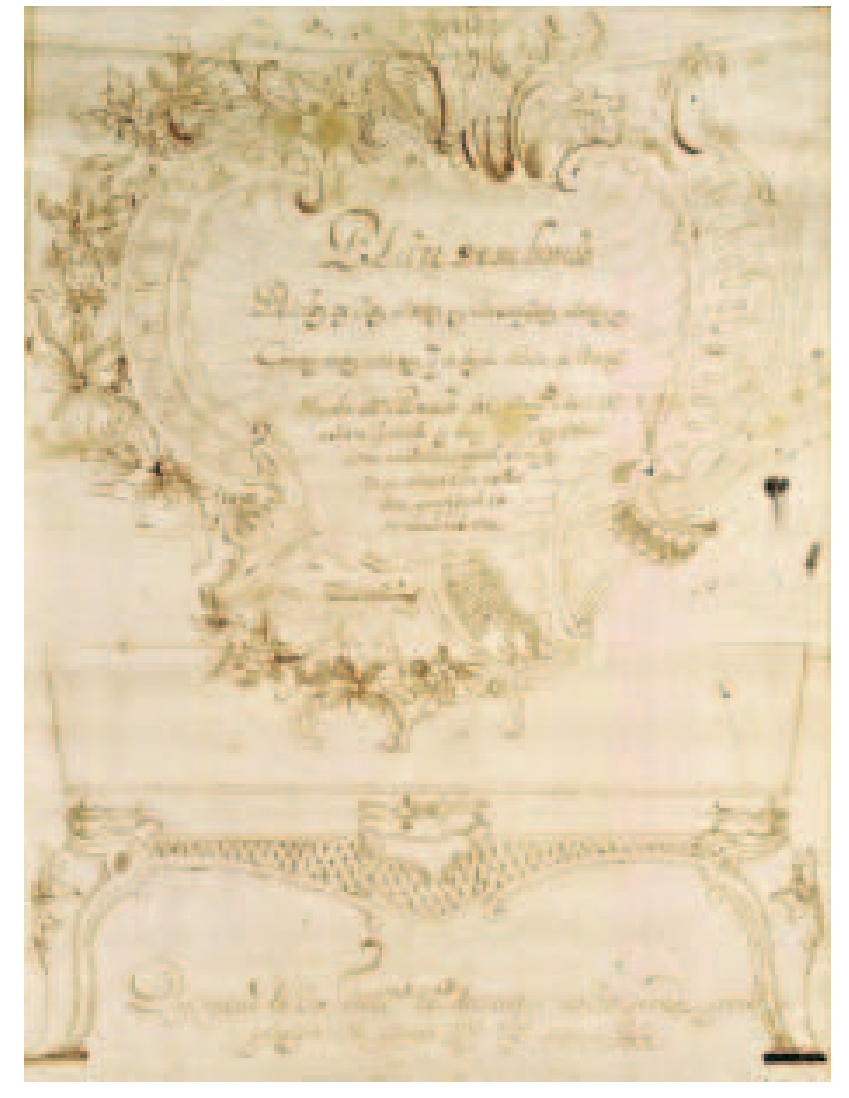

Fig. 19 - Frontispício de ZUZARTE, Teotonio José. "Plano em borrão de todos os rios, caxueyras e todas as couzas mais notaveis que vi desde o Porto de Araraytaguaba até a Povoação do Guatemy e dahi até a serra que divide as duas potencias fidelissima e católica; o qual será posto em limpo com melhor idea e perfeiçam como indo se não vio". [ 1769]. Fundação Biblioteca Nacional Rio de Janeiro.

ou vistas em perspectiva de vilas e cidades -, cujo instrumental e procedimentos advêm das belas-artes, mais especificamente do ramo da representação de paisagens.

A quadricula he huma grade, ou caixilho de madeira de quatro palmos e meyo de comprido, e tres de largo, e feita em boa esquadria; os quatro lados furados com furos miudos, e muy igualmente distantes huns dos outros, para passar por elles varios fios, ficando huns horizontaes, e outros perpendiculares; os quaes fios formaõ hum grande numero de quadradinhos perfeitos, e he tudo o que consta.

Para tomar a perspectiva de qualquer objecto se poem esta quadricula sobre hum pè na altura, que parecer de sorte, que olhando por elle, se veja o objecto, que se quer tirar em perspectiva: e a palmo e meyo de distancia da quadricula se suspenderà hum circulo de papelão delgado, que póde ser prezo à mesma quadricula por hum arame grosso, e poderá ter meyo palmo de diametro, e furado no meyo com hum buraquinho, e se puder ser, de modo, que se possa pôr em differentes situaçoens; mas em huma mesma vista deve estar firme, e no mesmo lugar.

No papel, ou borrador, em que se quer tirar a perspectiva, se terà riscado com lapis huma quadricula de outros tantos quadradinhos, e olhando pelo buraco do papelão para os objectos, que apparecem cada hum em seu quadrado, e sempre no mesmo lugar; porque o olho naõ póde mudar a respeito do buraquinho, em que se terminão todos os rayos visuaes; 
e assim se vão desenhando nos quadrados do papel os objectos relativos aos da quadricula, e postos todos em seus lugares: as mais miudezas se podem aperfeiçoar à vista (FORTES, 1722, p. 184-1851.

Desde os tempos de Dürer (Figura 20), o emprego da "quadrícula" é visível em alguns "borrões" setecentistas, tal como no Prospecto da Cidade do Rio de Janeiro, de autoria desconhecida, datado de ca. 1772 (Figura 21 ). Embora com defasagem de uma década, quiçá esboço e técnica semelhantes tenham sido usados no idêntico Prospecto (Figura 22), de 1760, realizado pelo engenheiro genovês Miguel Angelo Blasco.

Por sua vez, o engenheiro militar baiano, José Antonio Caldas, afirma empregar outro instrumento na feitura de tais "prospectos". Ao descrever os conteúdos ministrados na "Aula de Engenharia" da Bahia, em 1779, atesta o uso da câmara escura. Amplamente empregada na pintura de paisagem, também alcunhada "oculus artificialis teledioptricus"

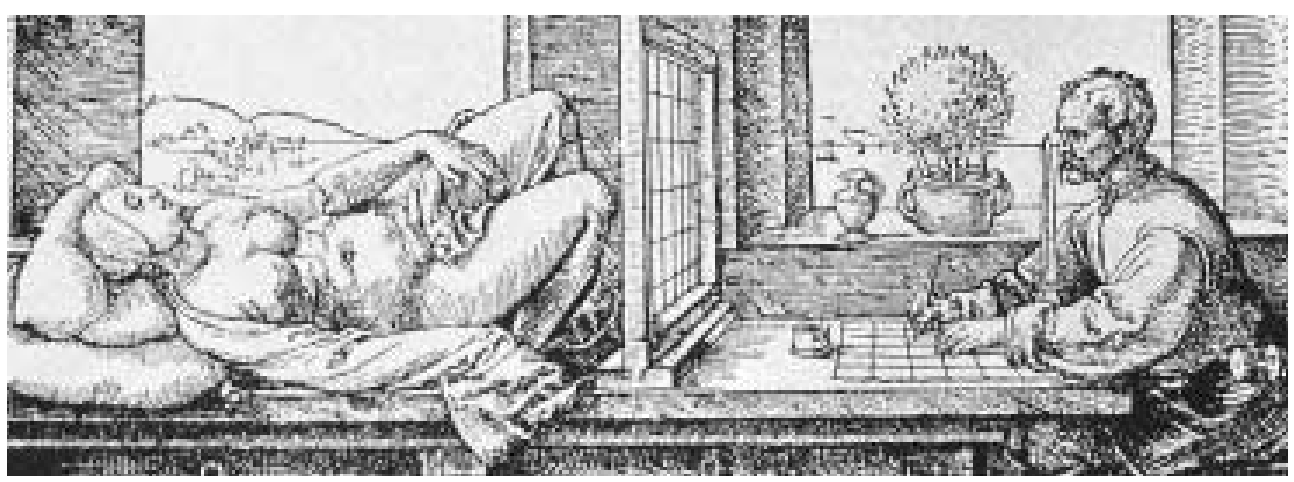

Fig. 20 - DÜRER, Albrecht. Unterweysung der Messung. Nuremberg, 1538. Kupferstichkabinett, Staatliche Museen Preussischer Kulturbesitz, Berlim. Fonte: ALPERS, S. El arte de describir. El arte holandês en el siglo XVII. Madrid: Hermann Blume, 1987, p. 83.

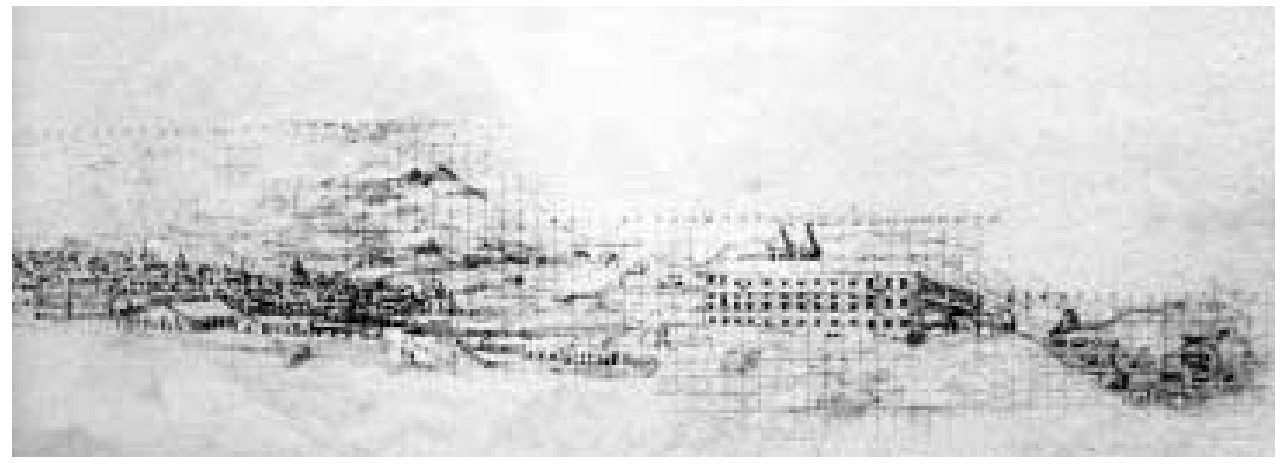

Fig. 21 - [Prospecto do Rio de Janeiro], c. 1772. Autor desconhecido. Casa da Ínsua, Castendo, Portugal. Fonte: REIS FILHO, N. G. Imagens das vilas e cidades do Brasil Colonial. [Colaboradores Paulo Bruna e Beatriz Bueno]. São Paulo: EDUSP/FAPESP, 2000, p. 179. 


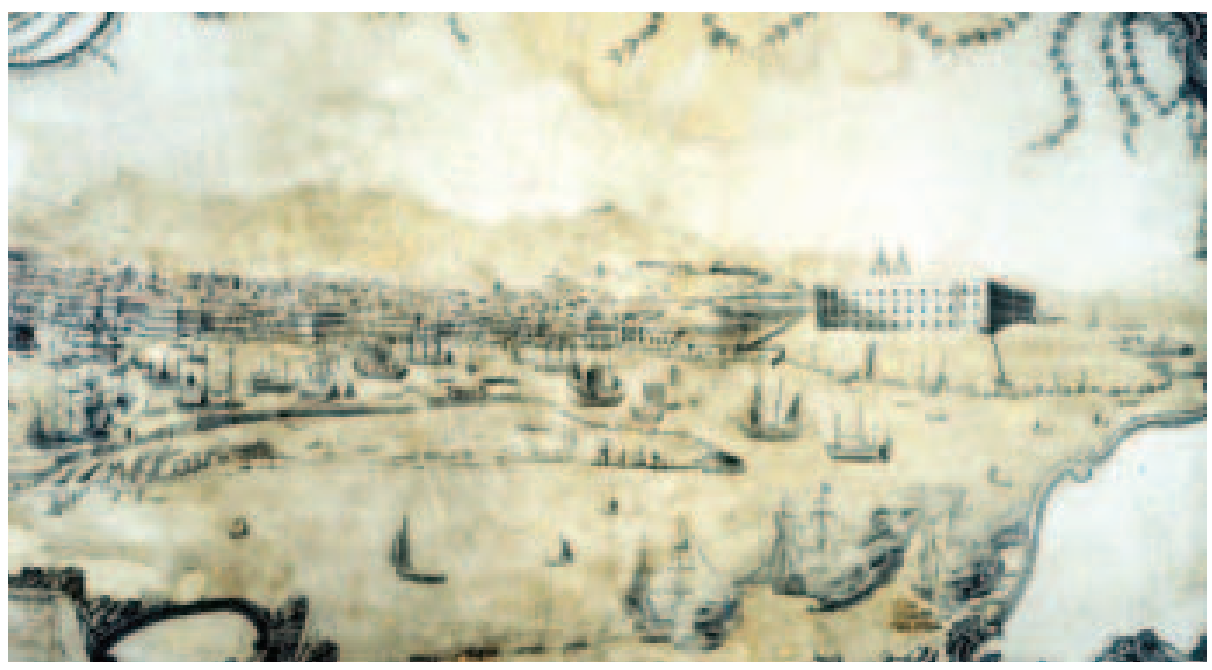

Fig. 22 - "Prospectiva da Cidade do Rio de Janeiro/Vista da parte do Norte, na llha das Cobras no baluarte mais chegado a $S$. Bento, da qual parte se vê diminuir em proporção o seu prospecto, até a barra, como o Risco representa. Elevada p. Ordem do IIImo e Ex mo Senhor Conde de Bobadella, a quem a Cide deve a mayor $p^{\text {te }}$ da sua pre ${ }^{\text {te }}$ Grande e Magñ ", 1760. Autor: Miguel Angelo Blasco. Arquivo Histórico do Exército - RJ. Fonte: REIS FILHO, N. G. Imagens das vilas e cidades do Brasil Colonial. [Colaboradores Paulo Bruna e Beatriz Bueno]. São Paulo: EDUSP/FAPESP, 2000, pp. 170-172.
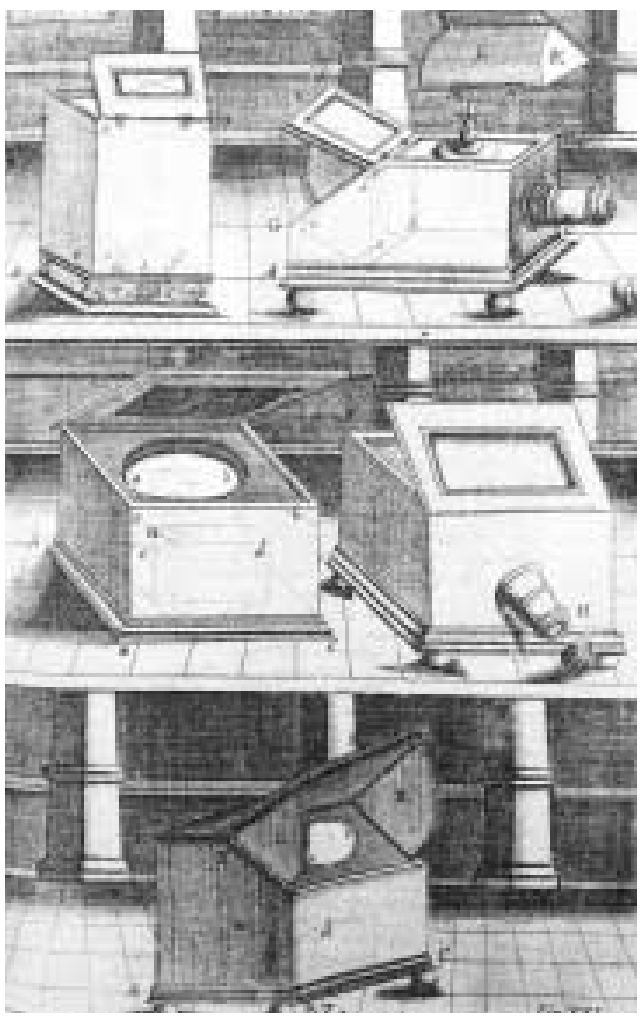

Fig. 23 - Câmaras escuras, In: ZAHN, Johannes. Oculus artificialis teledioptricus. Würzburg, 1685. Fonte: KEMP, M. The science of Art. Optical themes in western art from Brunelleschi to Seurat. New Haven and London: Yale University Press, 1990, p. 190. 
33. Sobre a câmara escura consultar: ALPERS 1987; KEMP, 1990, p. 190

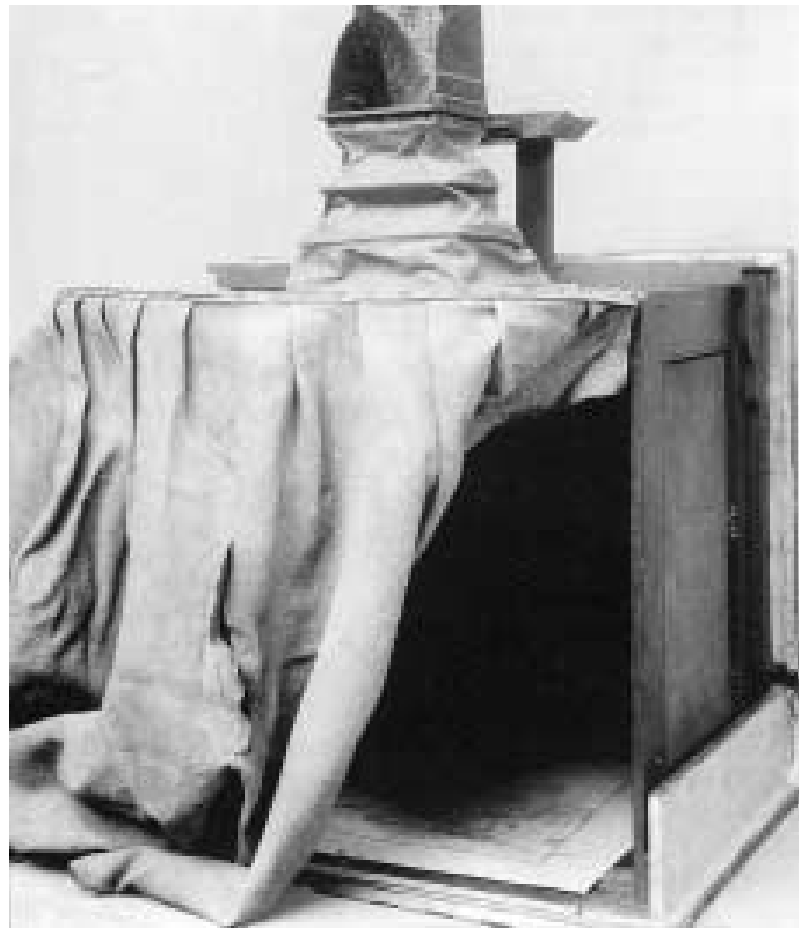

Fig. 24 - Câmara escura pertencente a Sir Joshua Reynolds. Science Museum, London. Fonte: KEMP, M. The science of Art. Optical themes in western art from Brunelleschi to Seurat. New Haven and London: Yale University Press, 1990, p. 198.

mais sofisticado. O funcionamento da câmara escura ${ }^{33}$ era semelhante ao da máquina fotográfica, diferindo apenas no fato de não fixar a imagem obtida. Tratava-se de um aparato que permitia, via espelho e lente, projetar sobre uma superfície a imagem do mundo exterior. Sobre a projeção colocava-se o papel e reproduzia-se a imagem. Dada a extensão dos "prospectos" das vilas e cidades, em geral, eram desenhados em várias folhas de papel, depois coladas umas às outras com "cola de Inglaterra".

A multifacetada atividade dos engenheiros encontra-se materializada em mapas e relatos, que hoje surpreendem, para além da estética, por seu rigor e pragmatismo, fruto do impulso renovador do ensino da ciência do desenho geográfico, desenvolvido num momento político-estratégico específico e levado a cabo pelo brilhante engenheiro-mor do reino, Manoel de Azevedo Fortes.

Tratados, desenhos e desígnios

A nomeação de Manoel de Azevedo Fortes para integrar a Academia Real de História, como encarregado das questões geográficas, insere-se numa 
conjuntura bastante específica, sobre a qual já escrevemos em outros trabalhos publicados em Portugal ${ }^{34}$, cabendo aqui apenas apontar algumas linhas gerais. Ao convocá-lo, D. João V pretendia prioritariamente promover o mapeamento do território brasileiro, de forma a fundamentar futuras negociações com Castela, já que o mapa-múndi e a dissertação apresentados por Guillaume Delisle, na Academia Real de Ciências de Paris, em 1720 - Determination Géographique de la Situation et l'etendue des differentes parties de la Terre - apontavam publicamente que a Colônia do Sacramento se situava além de Tordesilhas, não fazendo parte do território português como se pensava. Com objetivo de suprir a carência de engenheiros militares nacionais habilitados corretamente no exercício da profissão, Azevedo Fortes, na Representação feyta a S. Magestade, [...]. Sobre a forma, e direcçam, que devem ter os Engenheyros para melhor servirem ao dito Senhor neste Reyno \& suas Conquistas (1720), apontou as deficiências do ensino dessas matérias em Portugal, chamando atenção para a necessidade de novas diretrizes nos cursos e sugerindo a D. João $V$ que mandasse executar o decreto de D. Pedro II, datado de 20/7/1701, visando ao estabelecimento de novas academias de fortificação nas províncias do reino e estados ultramarinos destinadas a formar engenheiros.

Com o intuito de suprir a carência de livros em língua portuguesa sobre o desenho das cartas geográficas e necessitando constituir imediatamente uma equipe de trabalho orientada segundo um método comum, Azevedo Fortes anunciou em maio de 1721, em sessão proferida na Academia Real de História, sua intenção de redigir um tratado, publicado no ano seguinte sob o título Tratado do Modo o mais facil e exacto de fazer as cartas geographicas, assim de terra como de mar, e tirar as plantas das praças (1722). Questões específicas referentes aos levantamentos topográficos, desenho e aquarelamento dos mapas foram depois detalhadas na obra O engenheiro portuguez, publicada em 1728/1729.

resultado é uma série preciosa de mapas, que produzida de acordo com os mais modernos padrões de representação da época, cumpriu funções estratégicas no âmbito dos desígnios da Coroa portuguesa daquele momento.

Sobre o conceito de "território" e suas vinculações com a cartografia

Território ${ }^{35}$ e espaço não são noções equivalentes. $\bigcirc$ território com contornos e limites precisos é uma construção histórica, produto da ação humana. Categoria aparentemente universal, falsamente natural, o território não tem nada de espontâneo. Para além das fronteiras naturais, a fronteira política é sempre uma linha abstrata e convencionada por alguns. Tal como os animais se apropriam da natureza definindo territórios, os homens "dilatam as suas conquistas", apropriam-se do espaço, percorrendo-o, conhecendo-o, nomeando-o e mapeando-o.

Como vimos, por meio de uma trama ortogonal de paralelos (latitudes) e meridianos (longitudes), mapas são a "pintura do mundo", capazes de
34. BUENO, 1998, p. 87 $118 ; 2000$, p. $40-58$

35. Conforme alerta o jurista francês Paul Alliès, o território com contornos e limites precisos não é uma categoria universal, mas historicamente constituída e fruto da ação humana:"Territoire: rare jusqu'au XVIIe s.; répandu au XVIIIe', dit le Littré [...] Le mot est donc d'invention récente, si l'on veut bien prendre l'échelle du temps historique. Pourtant les juristes ont fait du territoire une catégorie quasi universelle: le territoire, lit-on encore aujourd'hui dans bien des manuels de droit constitutionnel, est un élément constitutif de l'Etat. Le territoire est ainsi devenu l'expression juridique d'une donnée faussament naturelle. Les juristes ont réussi à confondre territoire et espace, et à naturaliser par ce procédé l'Etat bourgeois. Pourtant, le territoire n'a rien de spontané. Si on se penche sur sa découverte par l'Etat absolutiste et sur sa production par l'administration d'alors, on doit bien considérer son caractère relatif et contigent. Le territoire n'est pas cette donnéé à peu près indiscutable parce que géographique que la doctrine juridique a installée à la base de son analyse de l'Etat. Il est un des premiers appareils d'Etat que l'administration a su engendrer et reproduire, avant que la Révolution bourgeoise n'en tire le maximum de profit. L'analyse présentée ici n'est rien d'autre qu'une découverte des modes de production de ce territoire faussement innocent;1'histoire d'une invention que nous avons fini par prendre pour notre environnement naturel et spontané". Cf.ALLIÈS, 1980. 
representar graficamente, na bidimensionalidade do papel, a tridimensionalidade do real, conservando-the as proporções. A negociação e legitimação da posse em grande parte só se viabilizam por meio dessas folhas de papel que propiciam a compreensão visual de vastas áreas de outra forma inapreensíveis. Às terras interiorizadas, quiçá percorridas, mas não oficialmente mapeadas, dava-se o nome de "sertão" - "região apartada do mar, \& por todas as partes metida entre terras" (BLUTEAU, 1712, v. 7, p. 613) - cabendo à ação humana dilatar-the os "confins" - "fronteiras" ou "extremidades de huma terra contigua com outra". Mapear significava conhecer, domesticar, submeter, conquistar, controlar, contradizer a ordem da natureza. Nos mapas produzia-se um território limitado e contínuo sobre uma natureza descontínua e ilimitada. Nos mapas, natureza e índio foram progressivamente relegados à ornamentação das molduras de títulos e legendas, imperando uma reapresentação do real pautada em códigos e convenções abstratas (Figura 25).

Neste ensaio interessou-nos particularmente focalizar a dimensão técnica da produção cartográfica setecentista, em Portugal, analisando a natureza específica dos mapas legados pelos engenheiros militares, do ponto de vista dos seus modos de produção e sua materialidade. No entanto, consideramos fundamental a análise de outros aspectos da problemática, tais como a dimensão retórica da cartografia e os desígnios políticos em questão, para os quais

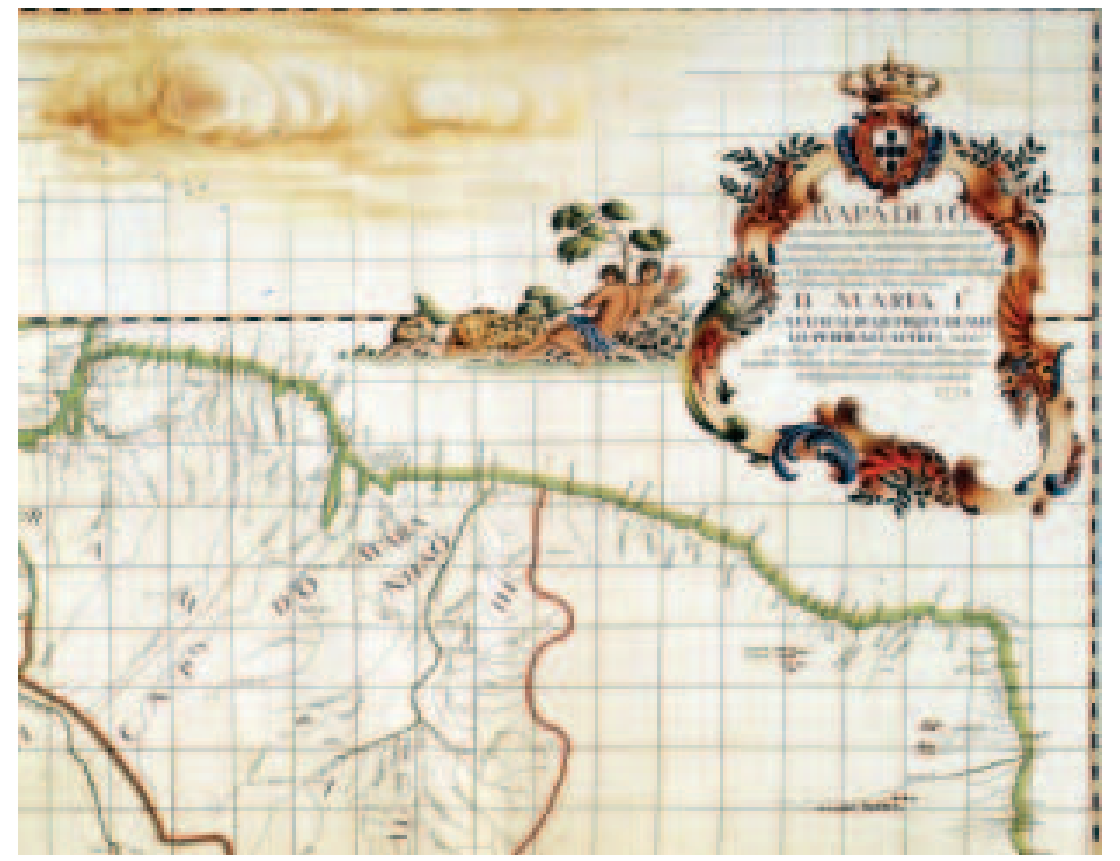

Fig. 25 - Detalhe do cartucho do "Mapa de todo o vasto Continente do Brasil ou América Portugueza com as Fronteiras respectivamente constituídas pelos Dominios Espanhoes adjacentes", 1778. Dimensão: $182 \times 141 \mathrm{~cm}$. Mapoteca do ltamaraty - RJ. 
indicamos a leitura do capítulo $V$ da nossa tese de doutorado (BUENO, 200 1). Não podemos deixar de mencionar que esses mapas cumpriram um papel estratégico como mediadores das ações oficiais da Coroa portuguesa no processo de colonização do Brasil. São "desenhos-desígnios"36 e, como tais, produtos e vetores de uma ação colonizadora. Produtos, na medida em que eram oriundos de uma conjuntura de expansão ultramarina e controle de territórios conquistados, na qual o aperfeiçoamento das técnicas de mapeamento geográfico, corográfico e topográfico era fruto de um permanente investimento por parte das Coroas européias. Vetores (veículos) das ações oficiais, na medida em que mediaram a viabilização dos principais desígnios político-estratégicos oficiais em territórios tão longínquos. Esses mapas nos dão idéia do alcance da multifacetada ação dos engenheiros militares no Brasil - braço direito da Coroa na viabilização dos seus intentos de domínio. Não por acaso, esses mapas hoje integram coleções pertencentes a ex-governadores de capitania - Casa da Ínsua ${ }^{37}$ e Arquivo de Mateus $^{38}$ da Biblioteca Nacional do Rio de Janeiro - ou acervos de antigas instituições oficiais - Arquivo Histórico Ultramarino de Lisboa lantigo Conselho Ultramarino), Arquivo Militar de Lisboa, Gabinete de Estudos Arqueológicos de Engenharia Militar de Lisboa, Arquivo Histórico do Exército do Rio de Janeiro, entre outros. Trata-se de assuntos de Estado, circulando num universo restrito da esfera administrativa portuguesa e permanecendo em boa parte manuscritos até fim do século XVIII.

O Brasil representado nos mapas setecentistas é o Brasil de além de Tordesilhas, com uma rede de caminhos, capelas, freguesias, vilas, cidades e fortificações - elementos que funcionaram como chaves de um território, cuja produção foi resultado de enorme investimento estratégico, minuciosamente projetado pela Coroa portuguesa. $O$ desenho do território assumiu formas diferenciadas ao longo do período entre os séculos XVI e XVIII. Sertanistas dilataram os limites até então oficialmente estabelecidos pela abstrata e convencionada linha de Tordesilhas. Em termos de organização administrativa, os contornos das capitanias seiscentistas e setecentistas diferiram muito das abstratas faixas convencionadas com a introdução do sistema de capitanias hereditárias, em 1534. Excetuada a área do Uruguai lantiga Colônia do Sacramento) e acrescido o atual estado do Acre, podemos dizer que no século XVIII foi produzido o território que hoje reconhecemos como Brasil (Figura 26).
36. Há uma vinculação semântica entre as palavras desenho e desígnio entre os séculos XV e XVIII; são sinônimos inclusive de "projeto".Cf.BUENO,2001.

37. Coleção particular de Luís de Albuquerque Pereira e Cáceres, governador da Capitania do Mato Grosso, na segunda metade do séc. XVIII.

38. Coleção particular do Morgado de Mateus, governador da Capitania de São Paulo entre 1765 e 1775. 


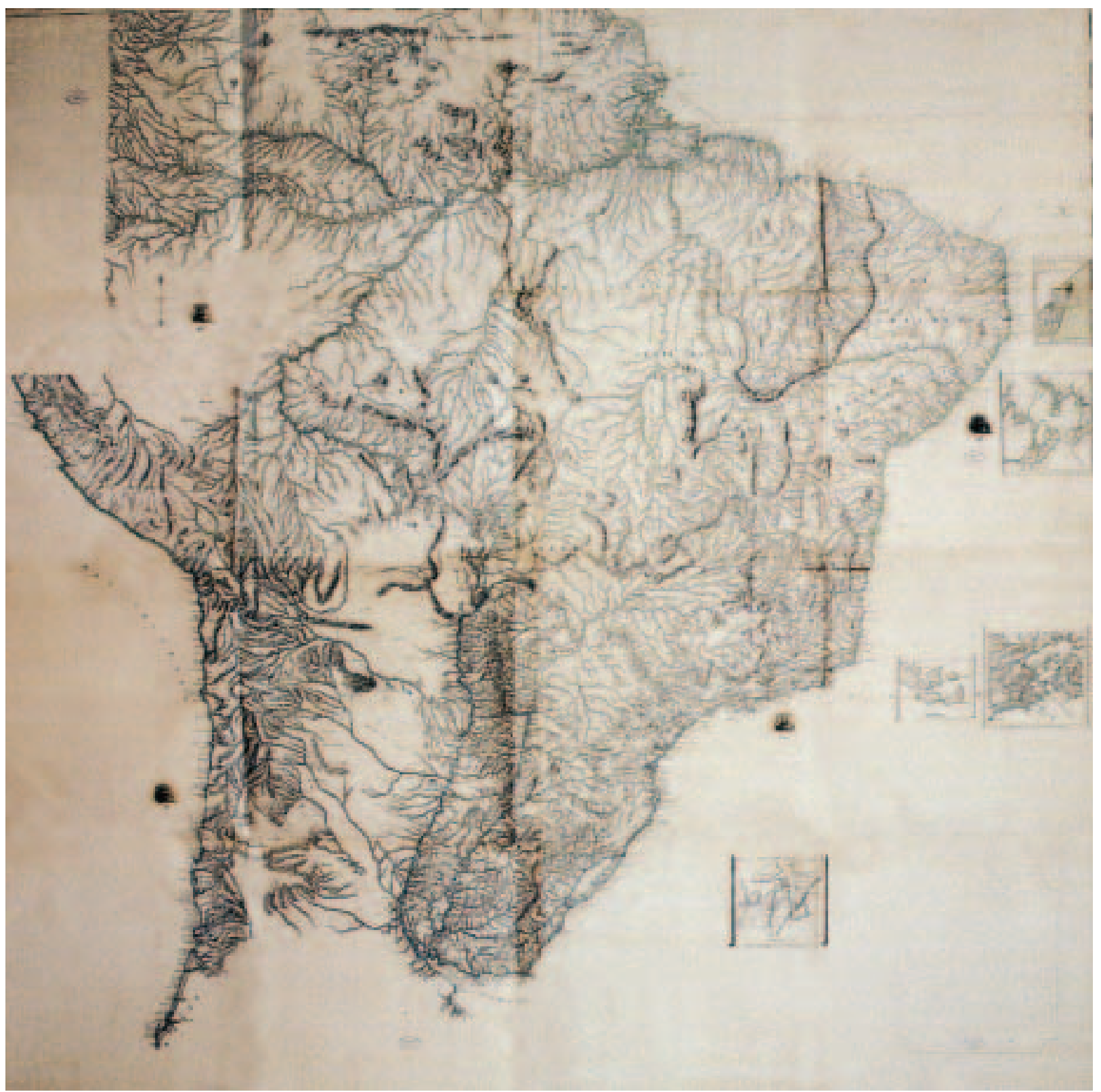

Fig. 26 - "Carta Geral do Brasil", 1779. Autor: José Custódio de Sá e Faria. Dimensão: 233 × 202cm. Gabinete de Estudos Arqueológicos de Engenharia Militar de Lisboa - GF - 9994/3-38-52. 


\section{REFERÊNCIAS}

ÁVILA,A. Barroco mineiro: glossário de arquitetura e ornamentação. 3 ed. Belo Horizonte: Fundação João Pinheiro, 1996.

ÁVILA, C. Relação texto-imagem no Barroco mineiro. Breve estudo de iconografia colonial. 1993. Dissertação (Mestrado) - Escola de Comunicação e Artes, Universidade de São Paulo, São Paulo, 1993.

ALLIÈS, P. L'invention du territoire. Grenoble: Presses Universitaires de Grenoble, 1980.

ALPERS, S. El arte de describir. El arte holandês en el siglo XVII. Madrid: Hermann Blume, 1987.

BLUTEAU, R. Vocabulario portuguez e latino... Coimbra: Collegio das Artes da Companhia de Jesus, v. 3, 1712 .

BUCHOTTE. Les règles du dessein et du lavis, pour les plans particuliers des ouvrages $\varepsilon$ des bâtimens, E pour leurs coupes, profils, élevations \& façades, tant de l'architecture militaire que civile: comme aussi pour le plan en entier d'une place;pour les cartes particulières, $\mathcal{E}$ pour celles des elections, des provinces, \& des royaumes. Paris: Chez Claude Jombert, 1722.

BUENO, B. P. S. A iconografia dos engenheiros militares no século XVIII: instrumentos de conhecimento e controlo do território. In: CARITA, H; ARAÚJO, R. Coletânea de estudos: universo urbanístico português 1415-1822. Lisboa: CNCDP, 1998.

. Desenho e desígnio: o Brasil dos engenheiros militares. Oceanos [A construção do Brasil urbano], Lisboa, n. 41, p. 40-58, 2000.

Desenbo e desígnio: o Brasil dos engenheiros militares (1500-1822). 2001. Tese (Doutorado) - Faculdade de Arquitetura e Urbanismo, Universidade de São Paulo, São Paulo, 2001 (consultar versão revisada em 2003).

BUISSERET, D. (Org.). Monarchs, ministers and maps. The emergence of cartography as a tool of government in early modern Europe. Chicago \& London:The University of Chicago Press, 1992.

CARTOGRAFIA e diplomacia no Brasil do século XVIII. Lisboa: CNCDP, 1997.

CARVAlHO, R. de. A astronomia em Portugal no século XVIII. Lisboa: Ministério da Educação/Instituto de Cultura e Língua Portuguesa, 1985.

DAINVILLE, F. Le langage des géographes. Termes, signes, coulaeurs des cartes anciennes 15001800. Paris, 1964.

EHRENSVÄRD, U. Color in cartography: A historical Survey. In: WOODWARD, D. Art and cartography. Six historical essays. 1987.

Annals of Museu Paulista.v. 12. Jan.-Dec. 2004. 
FERRAND DE ALMEIDA,A. Os jesuítas matemáticos e os mapas da América portuguesa (17201748). Oceanos, Lisboa, n. 40, p. 79-92, 1999.

FORTES, M. A. Tratado do modo o mais fácil e exacto de fazer as cartas geographicas. 1722. O engenbeiro portuguez. 1728/1729. $2 \mathrm{v}$.

GADOL, J. Leon Battista Alberti. Universal man of the early renaissance. 2 ed. Chicago/ Londres: The University of Chicago Press, 1973.

GALLUZZI, P. L’Umanesimo e le scoperte geografiche. In: . Americo Vespucci tra Firenze e Brasile. Rio de Janeiro, 2000.

GAUTIER, H. L'art de laver; ou, nouvelle manière de peindre sur le papier. Lyon, 1687.

HEAWOOD, E. Watermarks mainly of the 17 th and 18 th centuries. In: LABARRE, E. J. (Ed.) Monumenta chartae papyraceae. Historiam illustrantia or collection of works and documents illustrating the bistory of paper. Hilversum:The Paper Publications Society, 1950.

JACOB, C. L'empire des cartes. Approche théorique de la cartographie à travers l'bistoire. Paris: Editions Albin Michel, 1992.

. Disegnare la Terra. In: SETTIS, S. (Org.). I greci. Storia, cultura, arte, società. Torino: Giulio Einaudi Editore, 1996.

KEMP, M. The science of Art. Optical themes in western art from Brunelleschi to Seurat. New Haven/London: Yale University Press, 1990.

NUTI, L. Misura e pittura nella cartografia dei secoli XVI-XVII. Storia Urbana, v. 17, n. 62, p. 5-34, 1993.

REIS FILHO, N. G. Imagens das vilas e cidades do Brasil colonial. São Paulo: Edusp/Fapesp, 2000. (Colaboradores Paulo Bruna e Beatriz Bueno)

SMITH, J. The Whole Art and Mistery of Colouring Maps and others Prints in Water Colours. In: The Art of Painting in Oyl. 3 ed., 1701.

SOBEL, D. Longitude:The true story of a lone genius who solved the greatest scientific problem of his time. New York: Penguin Books, 1995.

SOBEL, D.; ANDREWES, W. J. H. The Illustrated Longitude. New York:Walker and Company, 1998.

Artigo apresentado em 08/2004. Aprovado em 1 1/2004. 